\section{NOVA TELLVS}

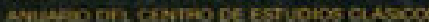

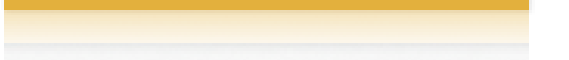

$\uparrow$
Nova Tellus

ISSN: 0185-3058

novatelu@servidor.unam.mx

Centro de Estudios Clásicos

México

Ramírez Batalla, Miguel Ángel

La actitud romana ante el pasado

Nova Tellus, vol. 25, núm. 2, 2007, pp. 231-272

Centro de Estudios Clásicos

Distrito Federal, México

Disponible en: http://www.redalyc.org/articulo.oa?id=59115477007

- Cómo citar el artículo

- Número completo

- Más información del artículo

- Página de la revista en redalyc.org

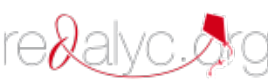

Sistema de Información Científica

Red de Revistas Científicas de América Latina, el Caribe, España y Portugal

Proyecto académico sin fines de lucro, desarrollado bajo la iniciativa de acceso abierto 


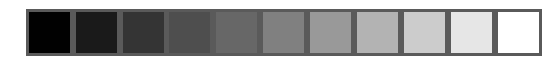

\title{
La actitud romana ante el pasado
}

\author{
Miguel Ángel RAMíREZ BATALlA \\ Universidad Nacional Autónoma de México \\ urbs753@latinmail.com
}

RESUMEN: El objetivo de este escrito es mostrar algunas líneas generales acerca de dos posturas que los romanos tuvieron sobre su pasado, una que defendía la permanencia de las costumbres como la principal característica de la historia romana y otra que señalaba al cambio. A pesar de que aparecían en contextos de disputa, estas visiones convivieron en la sociedad romana; sin embargo, esta situación no fue vista necesariamente como paradójica o contradictoria.

$$
* * *
$$

ABSTRACT: The objective of this writing is to show some general lines about two positions that Romans had about their past. One attitude defined the preservation of the habits like the principal feature of the Roman history, another one indicated the change. Although these visions were often in conflict, both coexisted in Roman society; however this situation was not seen necessarily paradoxical or contradictory.

PALABRAS ClAVE: actitud, cambio, costumbre, historia antigua, Roma. RECEPCIÓN: 10 de octubre de 2006.

ACEPTACIÓN: 25 de octubre de 2007. 

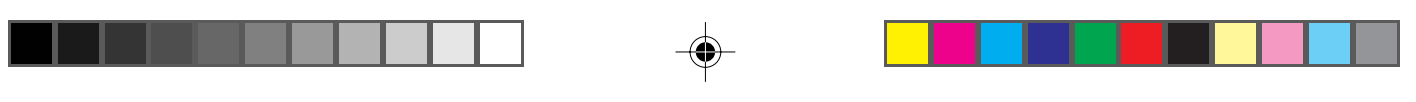

\title{
La actitud romana ante el pasado
}

\author{
Miguel Ángel RAMíREZ BATALlA
}

Toda sociedad tiene la necesidad de afrontar su pasado y tomar una posición respecto a él. Las diversas formas en que los grupos humanos perciben su historia reflejan el modo como desean verse y ser vistos por los demás. Sin embargo, esta visión no es unitaria ya que responde a los intereses de los distintos componentes de la comunidad, lo que ocasiona que se obtengan diferentes conclusiones partiendo de unos mismos hechos. Esto provoca la aparición de posturas encontradas que construyen una visión del pasado, la cual responde a necesidades del presente. En el caso romano esta situación es más complicada por su larga historia que provocó que cada grupo social y cada generación viera su pasado con diferentes ojos. Este trabajo presenta algunas líneas generales acerca de dos posturas que los romanos tenían sobre su pasado: una tradicionalista, que consideraba el respeto a las costumbres como el signo característico de la historia romana, y otra que pensaba que su rasgo primordial era el cambio que servía para mejorar.

De acuerdo con Eric Hobsbawm existen sociedades y comunidades para las cuales el pasado es un modelo para el presente. ${ }^{1}$

\footnotetext{
${ }^{1}$ Eric Hobsbawm, "El sentido del pasado", en Sobre la historia, p. 24.
} 

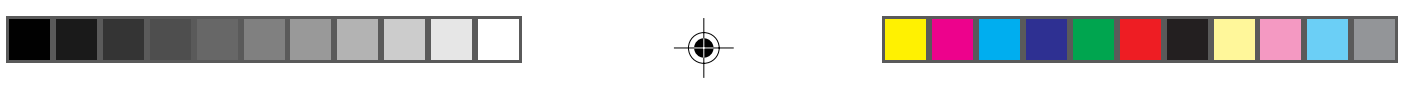

Según esta teoría, cada generación reproduce y copia a la que le precedió con la máxima fidelidad posible. Esta visión se presentó en algunos sectores romanos caracterizados por su tradicionalismo, quienes veían la continuidad como el principal rasgo de su historia. La cultura romana fue plenamente consciente de que había recibido un legado por parte de los mayores, lo cual se traducía en una postura reverente hacia los antiguos en varios rubros. Uno de los campos en que esta perspectiva resulta clara es la concesión de la ciudadanía romana. Desde su origen, la ciudadanía romana conllevaba el derecho de voto en la asamblea (ius suffragii), de ser elegido para las magistraturas (ius honorum), de contraer matrimonio con efectos legales (conubium) y de celebrar acuerdos comerciales (ius commercii). ${ }^{2}$ En el campo jurídico, el ciudadano romano contaba con un derecho que regulaba sus vínculos personales, comerciales y patrimoniales, también garantizaba el derecho a un juicio, la prohibición de ser sometido a tortura y la aplicación de penas menores que las utilizadas para los no ciudadanos. Igualmente podía engrosar las legiones en tiempos de guerra, lo cual le daba la posibilidad de obtener ascensos militares y una paga, especialmente después de la reforma militar de Mario, a fines del siglo II a. C. Debido a esto, la ciudadanía romana fue una condición apreciada desde sus orígenes hasta que Caracalla la concedió a los habitantes libres del Imperio en 212 d. C.

La concesión de dicha ciudadanía fue un proceso largo y complejo en el que varios factores estuvieron envueltos. La historiografía romana atribuía la concesión de la ciudadanía en la época monárquica a la necesidad de una población suficientemente capaz de brindar contribuyentes y soldados que afrontaran el sostén económico y la defensa de Roma: Tito

\footnotetext{
2 Juan de Churruca, Introducción histórica al Derecho Romano, pp. 86, 141146. Wolfgang Kunkel, Historia del derecho romano, pp. 76-77 y 82-83. Esto iba aparejado con la existencia de privilegios legales que se plasmaron en las categorías honestiores-humiliores que diferenciaban a los ciudadanos a partir del siglo II d. C.
} 

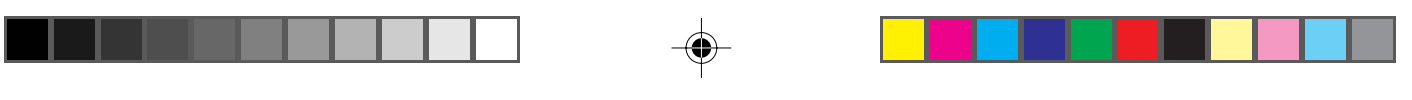

LA ACTITUD ROMANA ANTE EL PASADO / Noua tellus, 25•2, 2007, pp. 231-272

Livio y Dionisio de Halicarnaso dan numerosos ejemplos desde el asilo de los gemelos hasta el traslado de poblaciones enteras a la urbe y la creación de colonias. ${ }^{3}$ Posteriormente, a la caída de la monarquía, Roma se alió con los latinos, tras la victoria romana en el lago Regilo, y con los hérnicos para defenderse de enemigos comunes, estableciendo compromisos para las partes y creando colonias latinas en los territorios conquistados. Esta situación persistió hasta su enfrentamiento bélico con los latinos, entre 341 y 338 , debido a la supremacía romana sobre las otras partes y al temor latino por la ambición territorial romana.

La victoria de Roma condujo a que ésta tratara a sus vecinos conforme a la conducta que habían mantenido durante la guerra, lo que conformó un comportamiento típico romano en su trato con otros pueblos, y a la desaparición de ligas cuyos miembros quedaron vinculados a Roma por distintos lazos en cada caso. Además se fijaron diferentes tipos de relaciones en que los aliados eran suscritos a categorías jurídicas definidas por derechos y obligaciones hacia Roma. Esto fomentó la creación de ciudades con diferente estatus: aliados (socii), ciudades con ciudadanía romana pero sin derecho a voto (civitates sine suffragio), ciudades con autonomía y ciudadanía romana (municipia) y colonias de ciudadanos romanos (coloniae). ${ }^{4}$ Por otro lado, se reafirmó el derecho latino como un estado intermedio entre el romano y el peregrino. Con la expansión territorial romana y la aparición del sistema provincial, la ciudadanía fue un mecanismo que - junto con otros factores de diverso orden que tendieron a paliar los efectos más duros del dominio romano,

\footnotetext{
${ }^{3}$ Liv., I.8, I.28-29, I.33. Dion. Hal., Ant. Rom., II.15.3-4, II.35 y III.29.

${ }^{4}$ Tito Livio recoge la manera en que cada ciudad fue tratada por Roma tras la guerra latina, VIII.14. Sobre las condiciones de su alianza con los latinos antes y después de la guerra del 341-338, así como las discusiones respecto a esto vid. T. J. Cornell, Los orígenes de Roma, 1000-264 a. C. Italia y Roma de la Edad del Bronce hasta las guerras púnicas, pp. 341-352 y 400-405, y A. N. SherwinWhite, The Roman Citizenship, pp. 52-56 y 96-111.
} 

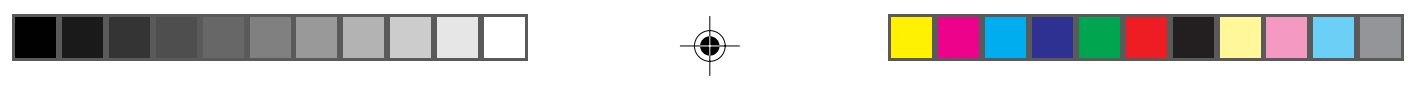

cuyos abusos habían sido evidentes - sirvió para atraer a las élites griegas y a las indígenas de Occidente y, de este modo, cohesionar los territorios conquistados.

En el caso griego, después de la resistencia de la liga aquea que llevó a la destrucción de Corinto en 146 a. C. por Lucio Mumio, se buscaron puntos de encuentro: los dirigentes griegos mantendrían la paz en sus ciudades y Roma respetaría su posición social. Esta comunión de intereses hizo que los grupos rectores griegos fueran defensores del régimen romano y se mantuvieran leales en los momentos críticos de la guerra contra Mitrídates, por lo que Roma los hizo puntales del nuevo sistema al otorgarles la ciudadanía romana. ${ }^{5}$

Durante el principado tal proceso continuó, teniendo como antecedente la actitud abierta de Julio César al conceder la ciudadanía, si bien con Augusto y Tiberio esta tendencia fue detenida para que no se interpretara como un desprecio a Italia y para impedir la entrada a los indignos dentro del marco de la restauración republicana. Empero, príncipes como Claudio, los Flavios, los Antoninos y los Severos apoyaron la concesión de la ciudadanía a distintos miembros de todas partes del orbe romano hasta que Caracalla otorgó la ciudadanía romana a los habitantes libres del Imperio en 212 d. C. con su Constitutio Antoniniana.

A lo largo de la historia romana hubo sectores que se opusieron a esta actitud debido a motivos patrióticos y adujeron el respeto al legado de los ancestros. Esta postura se proyectó al pasado. Así, Dionisio de Halicarnaso menciona que, en tiempo de Servio Tulio, los nobles estaban en desacuerdo con la propuesta regia de dar la ciudadanía a los libertos, pues consideraban a éstos indignos de tal honor y pensaban que se degradaba la ciudadanía de esta forma. ${ }^{6}$

\footnotetext{
${ }^{5}$ Géza Alföldy, Historia social de Roma, pp. 102-103.

${ }^{6}$ Dion. Hal., Ant. Rom., IV.22. Esta discusión sobre los libertos tenía efectos prácticos para la época de Dionisio, ya que la manumisión masiva de esclavos en
} 

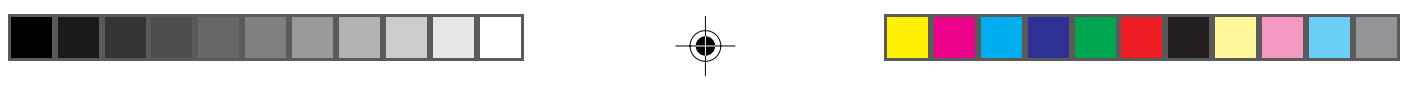

En el siglo IV a. C., los latinos solicitaron tener la ciudadanía romana, así como formar parte del senado y proveer un cónsul, "con el fin de que la sede de este imperio sea la misma y el mismo nombre para todos, puesto que una de las dos partes tiene que ceder, sea ésta, enhorabuena, la patria que prevalezca la cual redunde en bien de unos y otros, y llamémonos todos romanos". ${ }^{7}$ El grupo conservador del senado rechazó esta propuesta y Tito Manlio, uno de sus principales representantes, dijo "que en caso de que en los senadores hiciese presa una locura como para aceptar leyes de un hombre de Secia, él acudiría al senado ceñido con la espada y a todo latino que viese en la curia lo mataría con sus propias manos". ${ }^{8}$ Para gente como Manlio, los latinos eran extranjeros que no debían participar de la ciudadanía romana, por lo que, en vez de aceptar sus demandas, recuerda las victorias romanas sobre los latinos y apela a emular las gestas de los mayores. Un siglo después dicha tendencia reapareció tras la derrota de Cannas. Ante la falta de senadores y ciudadanos en Roma, Carvilio propuso que se otorgara la ciudadanía romana a senadores de las ciudades latinas para que ocuparan puestos en el senado romano, a lo que Tito Manlio y Fabio Máximo se negaron por razones de seguridad, ya que los aliados pedirían más privilegios

ese tiempo buscaba que éstos se beneficiaran de los repartos estatales de trigo, además de la consecuencia política por la que los libertos podían votar al convertirse en ciudadanos. Al señalar que debía volverse a la vieja costumbre de dar la libertad por mérito y controlar las manumisiones, Dionisio aprueba la política de Augusto de legislar sobre el número de manumisiones y el control de los derechos políticos de los libertos. Para las leyes de Augusto en torno a este tema, vid. Suet., Aug., XL-XLII.

${ }^{7}$ Liv., VIII.5.6: ut imperii eadem sedes sit idemque omnibus omen, quoniam ab altera utra parte concedi necesse est, quod utrisque bene vertat, sic haec sane patria potior et Romani omnes vocemur. Las citas latinas de esta obra provienen de la Scriptorum Classicorum Bibliotheca Oxoniensis y las españolas de la Biblioteca Clásica Gredos.

${ }^{8}$ Idem, VIII.5.7: ut, si tanta dementia patres conscriptos cepisset ut ab Setino homine leges acciperent, gladio cinctum in senatum venturum se esse palam diceret et quemcumque in curia Latinum vidisset sua manu interempturum. 

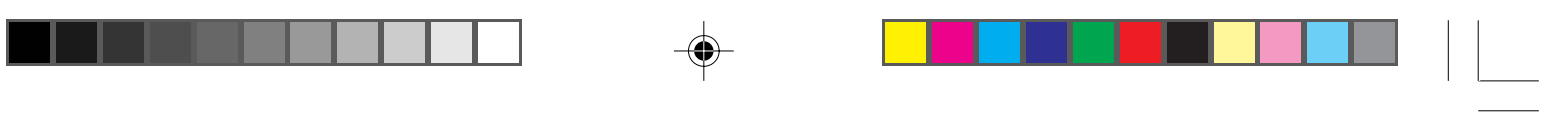

y esto no era conveniente tras la batalla de Cannas. Este proceder se repitió ante distintos intentos de concesión de ciudadanía realizados por Cayo Graco, Marco Fulvio Flaco y Livio Druso en los siglos II y I. ${ }^{9}$ Estas propuestas se enfrentaron al rechazo de grupos que utilizaron tales proposiciones para atacar políticamente a sus defensores y usaron razones patrióticas para definir lo "romano" como lo perteneciente a la Ciudad. Según dicha tendencia exclusivista, todo elemento externo a los muros de Roma era considerado incompatible con esta definición, por eso se buscó apoyo en el pasado para justificar esta posición y, de esta manera, presentarla como respetuosa del ejemplo de los antiguos.

\section{II}

Un sector clave que defendió esta postura fue la nobleza. Aunque de origen era cambiante, basta recordar que se nutrió de nobles extranjeros, ricos plebeyos, itálicos destacados y provinciales durante prácticamente toda su historia, la aristocracia se concibió como un grupo que no había sufrido modificaciones y que salvaguardaba las costumbres romanas. Su prestigiada posición social fue acompañada por su poder político y económico que la ubicó en la cúspide de la pirámide social, lo que le permitió validar su posición rectora en la sociedad romana e imponer sus valores. ${ }^{10}$ Esto fue evidente desde la lucha entre patricios y plebeyos que comenzó en el

\footnotetext{
${ }^{9}$ Alföldy, op. cit., pp. 103-104. En plena crisis republicana, el que Julio César diera la ciudadanía a algunos galos, considerados bárbaros, fue visto como algo contrario a las costumbres patrias. Suet., Iul., LXXVI.

${ }^{10}$ Una revisión de las formas que sirvieron a la nobleza senatorial de época imperial para promover su imagen y reafirmar su sentido de grupo frente a los demás grupos sociales en Janet Huskinson, "Elite culture and the identity of empire", Experiencing Rome. Culture, Identity and Power in the Roman Empire, pp. 103-106.
} 

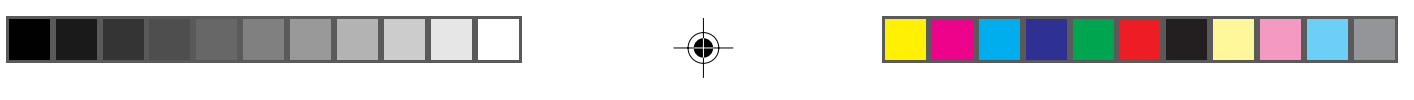

LA ACTITUD ROMANA ANTE EL PASADO / Noua tellus, 25•2, 2007, pp. 231-272

siglo v a. C., en la que los segundos pretendían participar de los privilegios que los patricios retenían. Tras la expulsión de los decenviros a mediados del siglo $\mathrm{V}$ a. C., el tribuno Canuleyo propuso el matrimonio entre ambos órdenes, lo que fue rechazado por los patricios. Éstos se apoyaban en el respeto a las tradiciones ancestrales que marcaban la separación de los órdenes, así la propuesta del tribuno socavaba el orden establecido sabiamente por los antepasados, lo cual era un atentado contra la historia romana y una llamada de atención hacia un aspecto valorado por los romanos: el respeto hacia la autoridad constituida y la preservación del orden. La petición de Canuleyo suponía la "confusión de familias, trastocamiento de auspicios públicos y privados, de forma que no existe nada limpio, nada puro; que, suprimida toda diferenciación, nadie pueda identificarse a sí mismo ni a los suyos". ${ }^{11}$

El acceso de los plebeyos a las magistraturas republicanas fue un proceso complicado con varios momentos álgidos y que se topó con la resistencia patricia hasta la aprobación de la ley Hortensia que dio fuerza de ley a los plebiscitos en 287 a. C., lo que marcó el fin del conflicto de órdenes y la aparición de una nueva nobleza formada por el viejo patriciado y los plebeyos más destacados. El patriciado fue renuente a esta incorporación plebeya, a pesar de que algunos nobles estaban abiertos a este hecho. Tal fue el caso de Apio Claudio, quien impulsó una serie de ambiciosas reformas a fines del siglo IV a. C., incluida la de admitir a hijos de libertos en el senado. Aunque algunas de estas medidas fueron anuladas por la nobleza poco tiempo después, marcaban una tendencia en la sociedad romana. Aun así, los nobles no dejaban de mostrar

\footnotetext{
${ }^{11}$ Liv., IV.2.5: conluvionem gentium, perturbationem auspiciorum publicorum privatorumque adferre, ne quid sinceri, ne quid incontaminati sit, ut discrimine omni sublato nec se quisquam nec suos noverit. Un resumen de la evolución de la lucha de órdenes en Leon Homo, Evolución social y política de Roma, pp. 41-48.
} 

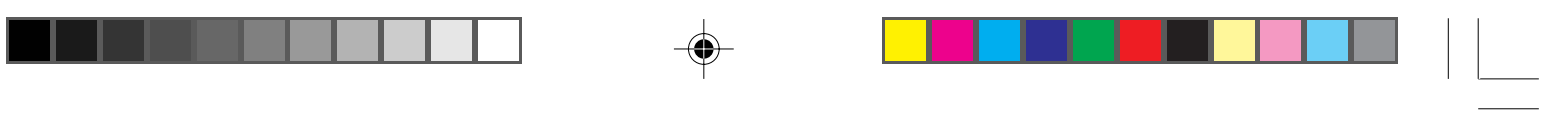

su inconformidad ante esta situación y su desprecio a quien arribaba a posiciones de poder. Por ejemplo, el tribuno Flavio fue mal visto por los nobles por ser nieto de libertos y, cuando llegó a ser edil curul, se negaron a darle las muestras públicas de respeto hacia su cargo. Tito Livio capta el sentir de los nobles y la visión que tenían de sí mismos al señalar que, desde entonces, "la población se dividió en dos bandos: la gente honesta, que apoyaba y honraba a los buenos, pretendía una cosa, el partido del foro otra". ${ }^{12}$

Esta postura fue alentada por los triunfos de Roma sobre Pirro hasta la incorporación de los reinos helenísticos. Tal política expansionista promovida y dirigida por la nueva nobleza se mostró exitosa y certificó su posición dirigente, ya que fue la principal beneficiaria de las conquistas. La aristocracia tenía los medios políticos, económicos y sociales para acaparar las magistraturas y reproducirse como grupo. Su experiencia basada en el ejercicio de puestos públicos, su prestigio que le garantizaba el apoyo de diversos grupos, su capacidad económica para tener cargos no pagados y sus numerosos clientes que votaban a su favor le aseguraba su permanencia en el poder. En el plano ideológico, los nobles se jactaban de sus ancestros magistrados, generales y sacerdotes que habían contribuido con sus hazañas a la grandeza romana. Este hecho les brindaba un gran reconocimiento a sus descendientes y les aseguraba un privilegiado lugar en el cuerpo social; a su vez, estos nobles podían continuar con la tradición familiar y contribuir con sus propias hazañas a engrandecer el linaje. Para un hombre nuevo era muy difícil destacar en estas circunstancias, ya que los aristócratas concebían las magistraturas como suyas y eran reacios a permitir que otros las obtuvieran,

\footnotetext{
${ }^{12}$ Liv., IX.46.13: in duas partes discessit civitas, aliud integer populus, fautor et cultor bonorum, aliud forensis factio tenebat. Sobre las medidas polémicas de Apio Claudio, sus intenciones y la significación histórica de este personaje vid. Cornell, op. cit., pp. 427-431.
} 

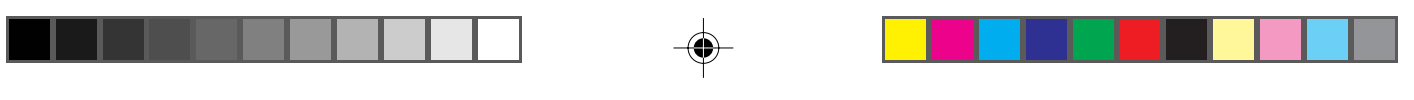

lo que explica que entre 191 y 107, cuando Acilio Glabrión y Mario ocuparon el consulado respectivamente, sólo dos homines novi accedieron a tal puesto, mientras que en el mismo periodo los linajes más afamados ejercieron esta magistratura varias veces. ${ }^{13}$ La crisis republicana produjo el ascenso de varios elementos nuevos que aprovecharon la coyuntura y sus propias habilidades para hacerse con posiciones de poder. Empero, la nobleza seguía creyendo aberrante que el consulado fuese ocupado por hombres nuevos, estimados indignos de tal cargo e impuros a causa de su origen humilde. Salustio refiere un ejemplo acerca de la actitud de varios aristócratas en torno a Cicerón y sus intenciones de llegar a ser cónsul, ya que "contaba con la malquerencia de muchos nobles, persuadidos de que era profanar dicha magistratura consentir que la ocupase un hombre nuevo, por ilustre que fuese". ${ }^{14}$ Más adelante añade que Catilina usó su afamado origen como argumento para defenderse de las acusaciones de Cicerón, pues pedía "que no pensaran que un noble como él, a quien como a sus antepasados debía la plebe muchísimos beneficios, tuviera en interés arruinar la república, y en que viniese a salvarla un forastero advenedizo en la ciudad de Roma". 15

Después de las guerras sociales a principios del siglo I a. C., que provocaron la concesión de la ciudadanía a los aliados, y el apoyo ofrecido por Italia a Octavio contra Marco Antonio, los lazos de Roma con Italia se estrecharon y produjeron un sentido de unidad frente a las provincias, lo que se tradujo en

\footnotetext{
${ }^{13}$ Alföldy, op. cit., pp. 69-70. Salustio indicaba que la nobleza consideraba el consulado como suyo, por lo que el hombre nuevo, por ilustre que fuera, estaba manchado por su bajo origen. Sall., Iug., LXIII.6.

${ }^{14}$ Sall., Cat., XXIII.6: pleraque nobilitas inuidia aestuabat et quasi pollui consulatum credebant, si eum, quamuis egregius, homo nouos adeptus foret. Tanto las citas latinas como las españolas de esta obra provienen de la Bibliotheca Scriptorum Graecorum et Romanorum Mexicana.

15 Idem, XXXI.7: Ne existumarent sibi patricio homini, cuius ipsius atque maiorum pluruma benificia in plebem Romanam essent, perdita republica opus esse, cum eam seruaret M. Tullius, inquilinus ciuis urbis Romae.
} 

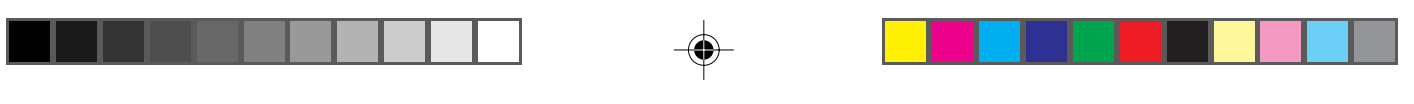

una política de preferencia de Italia por Augusto y Tiberio. Debido a esto, los senadores vieron mal la propuesta de Claudio de permitir el acceso de los galos al senado. Argumentaban que Italia podía proporcionar los miembros suficientes a este cuerpo, por lo que debía favorecerse a los itálicos nobles que pasaban por penurias económicas y darles distinciones. De este modo, la propuesta del emperador era considerada como una traición a las antiguas tradiciones, fuente de la hegemonía romana en el mundo, pues no había antecedentes que justificaran su tentativa. Además, los galos eran bárbaros indignos de tal honor, pues sus antepasados habían tomado Roma a principios del siglo IV a. C. y peleado contra Julio César en el siglo i a. C. Concluían que "disfrutaran del título de ciudadanía pero que no degradaran las insignias de los senadores y los honores de los magistrados". ${ }^{16}$

Tal forma de percibir lo romano y de acudir al pasado en búsqueda de apoyo continuó después de que sucesivos emperadores brindaran la ciudadanía a más grupos, incluso tras Caracalla. Un ejemplo es Severo Alejandro, quien se avergonzaba de su origen sirio, pues esto le hacía blanco de múltiples burlas al conocerse su disgusto porque le llamaran sirio. Este hecho lo llevó a inventar que su lugar de nacimiento era Roma y su linaje provenía de los Metelos. ${ }^{17}$ Un caso más dramático fue su sucesor Maximino Tracio que tenía padres bárbaros, lo cual lo volvió sumamente receloso e inseguro, porque conocía el desprecio del senado y del pueblo por su origen bárbaro y humilde, pues se corría el rumor en las calles de Roma de que había sido pastor en su natal Tracia. Las obras antiguas captan

\footnotetext{
16 Tac., Ann., XI.23: fruerentur sane vocabulo civitatis: insignia patrum, decora magistratuum ne vulgarent. Las citas latinas de esta obra provienen de la Scriptorum Classicorum Bibliotheca Oxoniensis y las españolas de la traducción de Crescente López de Juan, Alianza Editorial. Un siglo antes, Julio César había elevado a algunos galos al senado, lo que provocó la aparición de carteles y cantos que se pronunciaban en contra de esto. Suet., Iul., LXXX.

${ }^{17}$ SHA, Alex. Sev., 28.7, 44.3 y 64.3.
} 

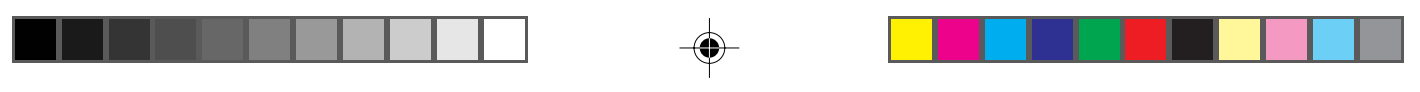

LA ACTITUD ROMANA ANTE EL PASADO / Noua tellus, 25•2, 2007, pp. 231-272

su rencor y complejos al haber sido tratado despectivamente incluso por esclavos en algunas casas antes de ser emperador, atribuyendo su carácter violento a estas muestras de rechazo y desprecio por su origen y a sus antepasados bárbaros. ${ }^{18}$

Así, en diferentes momentos históricos, hubo una directriz que limitaba la condición romana a un espacio geográfico, sin posibilidad de admitir una definición más flexible. Además, marcaba que el respeto a la práctica heredada y el no permitir modificaciones a lo dejado por los antiguos era el rasgo principal de la historia romana.

\section{III}

"Por sus viejas costumbres y hombres, dura el Estado romano". ${ }^{19}$ Esta cita de Ennio hecha por Cicerón refleja el concepto que la nobleza senatorial tenía sobre el peso de las mores maiorum en el pensamiento romano, al considerarlas como una de las bases más firmes del poderío y estabilidad de Roma. Igualmente esta noción muestra el modo en que la aristocracia aplicaba sus parámetros ideológicos a las demás capas sociales y, de esta forma, dejaba su marca en la identidad del pueblo romano. La transmisión de los hábitos antiguos desempeñaba un papel importante en la preservación del carácter romano y en el apego al orden constituido. La costumbre como herencia que debe preservarse tenía una función relevante al ayudar a cohesionar a los distintos grupos sociales en Roma bajo un mismo marco de valores y a fortalecer el Estado. Aunque los nobles eran los principales propulsores de esta idea, y los más beneficiados, también fue compartida por otros, pues se pen-

\footnotetext{
${ }^{18}$ Idem, Max., 1.7, 8.7 y 9.1-6. Hdn., VII.1.1-2.

${ }^{19}$ Cic., Rep., V.1: Moribus antiquis res stat Romana uirisque. Tanto las citas latinas como las españolas de esta obra provienen de la Bibliotheca Scriptorum Graecorum et Romanorum Mexicana.
} 

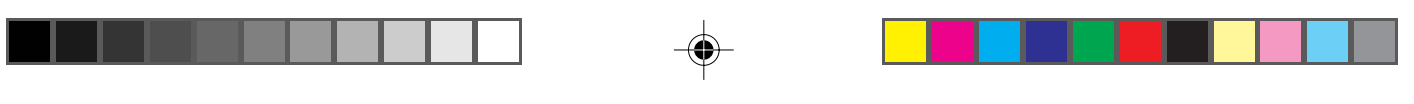

saba que todos contribuían al engrandecimiento de Roma de acuerdo con su papel social, lo cual se lograba siendo fiel al legado ancestral y conservándolo de generación en generación. De este modo, Polibio percibió bien tal dinámica al señalar:

Así se renueva siempre la fama de los hombres óptimos por su valor, se inmortaliza la de los que realizaron nobles hazañas, el pueblo no la olvida y se transmite a las generaciones futuras la gloria de los bienhechores de la patria. Y lo que es más importante, esto empuja a los jóvenes a soportar cualquier cosa en el servicio del Estado para obtener la fama que obtienen los hombres valerosos. ${ }^{20}$

Este concepto se evidenció en las reflexiones sobre el sistema político romano, el cual fue elogiado por parte de los autores antiguos, al considerarse la mezcla más acabada de las tres principales formas de gobierno del pensamiento clásico: monarquía, aristocracia y democracia. Así, el sistema romano combinaba el elemento regio, con los cónsules; el aristocrático, con el senado; y el democrático, con los comicios; con ello, aquél excluía los excesos de estos gobiernos por separado al tener cada unidad sus funciones claramente establecidas y al haber contrapesos. La sabiduría de esta constitución se veía en la cohesión del cuerpo social y su eficacia se reflejaba en la dominación de otros pueblos, igualmente explicaba su superioridad al compararla con otros regímenes. ${ }^{21}$

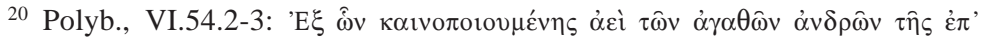

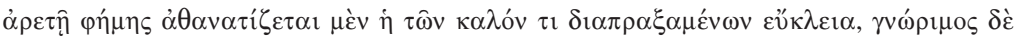

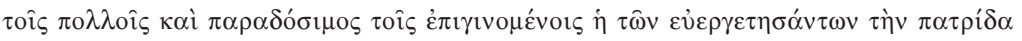

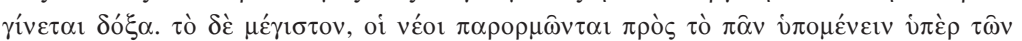

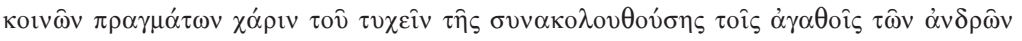

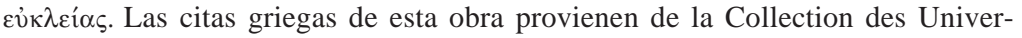
sités de France y las españolas de la Biblioteca Clásica Gredos.

${ }^{21}$ Idem, VI.3-13 y VI.43-52. Cic., Rep., I.48-70. Dion. Hal., Ant. Rom., II.717. A pesar de esta pretendida combinación y equilibrio de elementos, los autores antiguos eran conscientes de que en la constitución romana había un predominio
} 

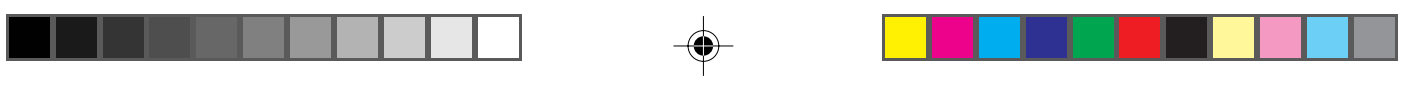

La alabanza de este gobierno por quienes lo vivieron en su etapa de esplendor y el anhelo nostálgico de los que vieron su declive coincidía en que el marco de referencia para la conducta presente era la obra de los mayores; la memoria colectiva de sus proezas y su imitación eran garantes de la continuidad de la grandeza romana. Seguir la constitución y heredarla tal cual era la clave para mantener el orden y el poder de Roma; seguir las normas y las instituciones establecidas era la acción a realizar para enfrentar cualquier desafío. Esta estructura se bastaba a sí misma, por lo que únicamente debía preservarse sin alteraciones porque había mostrado su valor: Cicerón hace decir a Escipión que ninguna constitución puede igualarse "con aquella que recibida desde entonces de sus mayores, nuestros padres nos dejaron". 22

Esta línea tradicionalista resultó muy útil para quienes buscaban conservar su posición en la crisis republicana, por eso veían el regreso al estado de cosas anterior a los conflictos civiles como la mejor solución a los problemas actuales. Educados en el respeto a la tradición, los nobles confirmaron su recelo hacia los cambios y su apego al orden establecido por el

de los intereses aristocráticos por criterios timocráticos que se remontaban a la reforma atribuida a Servio Tulio. Cic., Rep., II.40; Liv., I.43, y Dion. Hal., Ant. Rom., IV.20.

22 Cic., Rep., I.70: cum eam, quam patres nostri nobis acceptam iam inde a maioribus. Aunque sabían que el gobierno romano había cambiado con el tiempo, atribuían este sentir al pasado. Dionisio de Halicarnaso refiere que Rómulo propuso a sus hombres que escogieran el mejor gobierno para la nueva ciudad, si

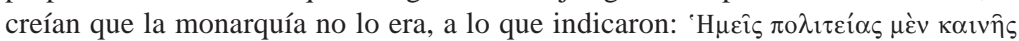

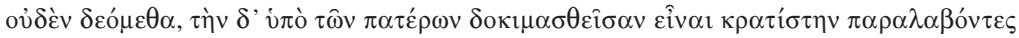

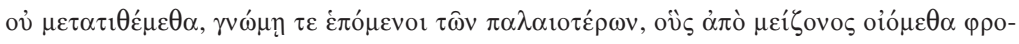

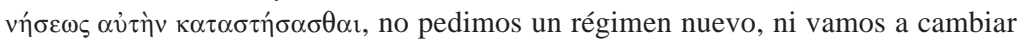
el que recibimos de nuestros padres, aprobado por ellos como el mejor. Seguimos la opinión de los antiguos, pues creemos que lo establecieron con la mayor sensatez (Ant. Rom., II.4.1). Las citas griegas de esta obra provienen de la Loeb Classical Library y las españolas de la Biblioteca Clásica Gredos. Dionisio incluso señala que Bruto, el padre de la república, aconsejó a los demás conjurados posponer la discusión sobre el gobierno más conveniente a la expulsión de Tarquinio, si había uno mejor que la monarquía (IV.73). 

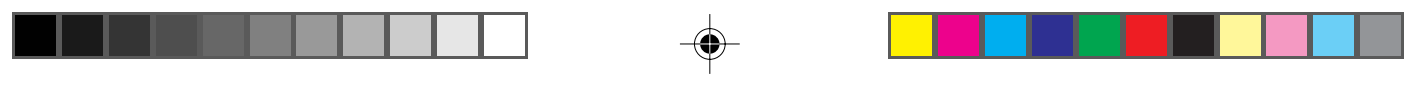

temor de ser desplazados de su posición política por el poder de uno. Por ello Salustio, en un pasaje conservado por Agustín, revelaba que el honor no era concedido por los servicios prestados a la patria, sino que la estima se daba a quien era rico y defendía la situación presente. ${ }^{23}$ El resguardo del gobierno heredado y forjado sabiamente por los ancestros fue una tesis utilizada ampliamente para defender que el respeto a la tradición caracterizaba a Roma.

Bajo esta óptica, cualquier desviación e innovación era reprobada y se le acusaba de provocar diversos males a Roma. Salustio presenta una visión idílica de la sociedad romana anterior a las guerras púnicas, caracterizada por el cultivo de las virtudes y el ansia de gloria obtenida por el servicio a la patria. Se competía por emular y superar las hazañas de los predecesores, el valor militar se mostraba frente al enemigo y el deseo de honra era más fuerte que el apego al dinero. Sin embargo, habiendo destruido Cartago, Roma no tenía rival y no había ningún obstáculo para que las pasiones se desbordaran, las mismas que el temor púnico había refrenado. Así, vicios como el lujo, la avaricia, la ambición, la mentira y el deseo del dinero y del poder dominaron a los romanos en una descripción que sirve para marcar en tonos oscuros a la sociedad de su tiempo y que tendrá eco en escritores posteriores; siglos después, Agustín de Hipona la recogerá para sus propios fines. Frente a la vacilación de algunos senadores sobre la condena de los secuaces de Catilina, Catón recuerda que las virtudes que forjaron la grandeza romana,

a nosotros absolutamente nos faltan: en el interior, actividad; fuera, una administración justa, un espíritu libre en sus deliberaciones y exento de la influencia de vicios y arbitrariedades. En vez de todo esto tenemos lujo y avaricia, pobreza oficial y opu-

\footnotetext{
${ }^{23}$ August., De Civ. D., III.17. Estas observaciones hicieron que Agustín considerara a Salustio un historiador veraz y sabio. Idem, I.5.
} 

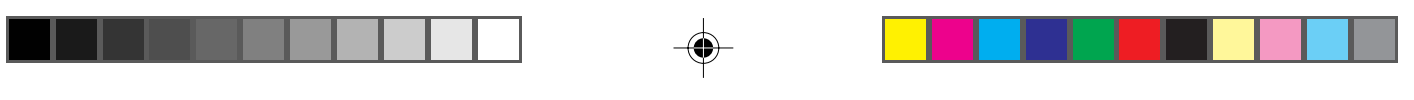

LA ACTITUD ROMANA ANTE EL PASADO / Noua tellus, 25•2, 2007, pp. 231-272

lencia en los particulares; queremos la riqueza y huimos del trabajo. ${ }^{24}$

Salustio recoge en el discurso de Catón su apelación al recuerdo de antiguos ejemplos de severidad romana que contrastan con la tibieza de su tiempo. A pesar de que había muchos otros factores envueltos en la descomposición de las estructuras republicanas, Salustio acertadamente capta el hecho de que Roma no tuviera un rival importante tras la victoria sobre Cartago lo que provocó la soberbia de la nobleza senatorial y que únicamente se fijara en sus propios intereses, marcando el lento declive de la república. El historiador se concentra en los efectos perniciosos de este entorno y lo traslada a un plano moral, atribuyendo los males de su época a la pérdida de las pautas tradicionales de conducta y valores que se vieron socavados por la presencia de elementos externos y nocivos. Para otros autores, el momento de inflexión fue el movimiento de los Graco, pero la supuesta concordia que se tenía antes de las luchas de clases y partidos se atribuía a la observancia de las tradiciones romanas; en cambio, los choques de la crisis republicana obedecían a que los hombres de esta época no renovaron ni conservaron los antiguos hábitos e introdujeron cambios perjudiciales provocando la decadencia de hombres, costumbres y gobierno. ${ }^{25}$

Esta traición a las costumbres se reflejó en varios campos, siendo el militar uno de los que más llamó la atención a los autores antiguos. La disciplina y valor de los soldados habían logrado la exitosa defensa de Roma de los ataques externos y habían puesto al mundo a sus pies. Las cualidades militares de ciudadanos libres que peleaban por su patria, la táctica, el

\footnotetext{
${ }^{24}$ Sall., Cat., LII.21-22: nobis nulla sunt, domi industria, foris iustus imperium animus in consulundo liber neque delicto neque lubidini obnoxius. Pro his nos habemus luxuriam atque auaritiam, publicam egestatem, priuatim opulentia. Laudamus diuitias, sequimur inertiam.

${ }^{25}$ Dion. Hal., Ant. Rom., II.11.2-3. Cic., Rep., V.1-2. Tac., Ann., III.27.
} 

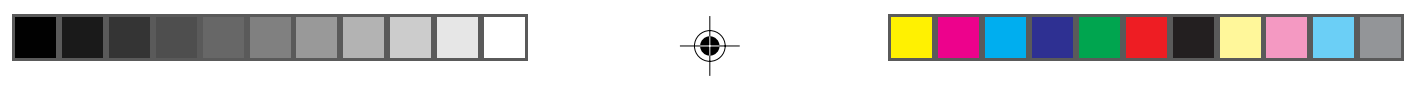

armamento y la correcta dirección de los generales servían a una causa común. No obstante, varios escritores remarcaban que las virtudes militares decayeron debido a que los generales ambiciosos de poder abandonaron la disciplina antigua para atraerse la lealtad de sus tropas. Algunos atribuían este cambio a Sila al permitir a sus soldados toda clase de excesos en campaña, a vivir en la molicie, disfrutar de placeres en lugar de entrenarse en ejercicios militares y saquear poblaciones para saciar su afán de riqueza. ${ }^{26}$ Tales actitudes estaban enfocadas a lograr el apego del soldado a su general para trasladar la lealtad al Estado hacia su persona y facilitar la consecución de sus metas; al mismo tiempo, el soldado favorecía a quien le aseguraba mejores condiciones como ascensos, paga y botines, lo cual era un fenómeno de la crisis republicana relacionado con la reforma militar de Mario. Este sentimiento de abandono de las virtudes militares siguió presentándose en el principado, aunque príncipes como Augusto y Tiberio fueron reconocidos por sus intentos de restablecer la vieja disciplina y por los triunfos que se plasmaron en anexiones al Imperio. Que el ejército podía promover rebeliones e imponer candidatos era algo que se sabía desde el inicio del principado, aunque los emperadores pudieron contener la ambición de sus generales relativamente bien. No obstante, uno de los rasgos más claros de la crisis del siglo III fue la participación de los soldados en golpes de Estado y la imposición de sus propios generales. Los autores de esta etapa con frecuencia atribuyen incapacidad, sedición, codicia, más deseo de saquear que de combatir y otros vicios al ejército. ${ }^{27}$ Amiano, quien había sido soldado, es muy crítico con la milicia y son comunes en su

\footnotetext{
${ }^{26}$ Sall., Cat., XI.5-7. Plut., Vit. Sull., XII-XIII.

27 Augusto y Tiberio: Suet., Aug., XXIV-XXV, y Tib., XIX. Comentarios negativos sobre el ejército del Bajo Imperio y algunos intentos por reformarlo: Hdn., II.6.1-3 y V.3-10-12. SHA, Avid. Cass., 6.4; Pesc. Nig., 3.6-12; Alex. Sev., 44.6. Eutr., VIII.23, IX.9.1 y IX.14. Aur. Vic., Caes., 17.7, 24.3, 26.6, 33.14, 34.7 y 35.1 .
} 

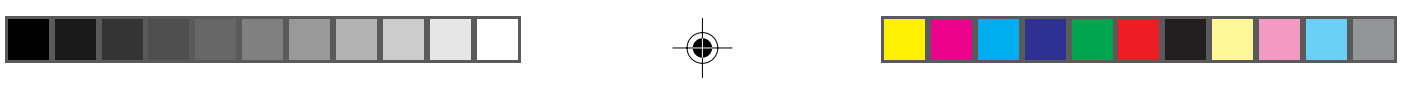

LA ACTITUD ROMANA ANTE EL PASADO / Noua tellus, 25•2, 2007, pp. 231-272

obra frases como las siguientes: el soldado era "más propenso por su natural ardor a las sediciones", "buscaban copas más pesadas que sus espadas (en efecto, les avergonzaba beber de la jarra) y casas marmóreas", "además el soldado era feroz y rapaz contra los suyos en aquellos tiempos, pero cobarde y débil con los enemigos". ${ }^{28}$ Las derrotas son explicadas por los vicios del ejército y éstos a su vez por la pérdida de la vieja disciplina, por lo que estos autores realizan alusiones nostálgicas sobre la milicia de los primeros tiempos republicanos y solicitan la vuelta hacia esas virtudes. De nuevo se perciben los efectos funestos que produjo el abandono de las costumbres que mantenían las cosas en su lugar.

IV

Esta postura tradicionalista convivió con otra más abierta a las modificaciones, de acuerdo con la cual la historia romana estaba caracterizada por el cambio. Nuevamente Hobsbawm señala que una forma de implantar innovaciones, sin mostrarlas como tales, es seleccionar los eventos que pueden ser recordados para desplazar el cambio a un segundo plano sin tener la sensación de haber alterado el pasado; además, el cambio consciente es posible con el argumento del regreso a una época o norma del pasado que había sido olvidada o ignorada. ${ }^{29}$ La historiografía romana sabía esto al admitir que, desde su ori-

\footnotetext{
${ }^{28}$ Amm. Marc., 16.12.14, 22.4.6-7: “in seditiones nativo calore propensioris", "et graviora gladiis pocula (testa enim bibere iam pudebat), quaerebantur et aedes marmoreae", "Adeo autem ferox erat in suos illis temporibus miles et rapax, ignavus vero in hostes et fractus". Las citas latinas de esta obra provienen de la Loeb Classical Library. Para distintas valoraciones sobre el ejército romano de este tiempo, sus problemas y la forma en que los autores antiguos lo afrontaron, vid. Averil Cameron, El mundo mediterráneo en la Antigüedad tardía 395-600, pp. 62-69, y Arther Ferril, La caída del Imperio Romano. Las causas militares.

${ }^{29}$ Hobsbawm, "El sentido del pasado", pp. 24-26.
} 

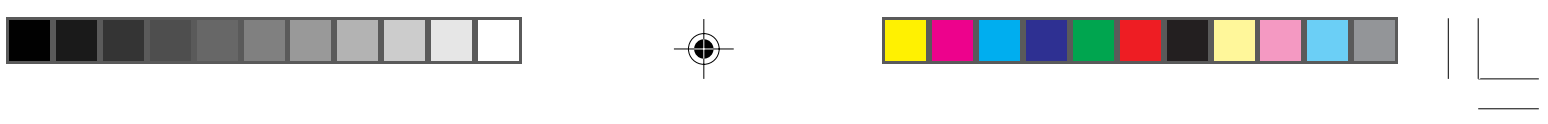

gen, Roma se caracterizó por su apertura a los extranjeros, a partir del asilo de Rómulo hasta la política de población que trasladaba grupos enteros a esta urbe, lo que se pensaba como una de las claves de su éxito. Dionisio de Halicarnaso indica que, ante los reproches del albano Meto, Tulo Hostilio afirmaba que los romanos no se avergonzaban

por haber hecho nuestra ciudad accesible a todos los que quisieron, que incluso nos enorgullecemos muchísimo de esta cuestión [...] nosotros, con unos pasos humildes, en no mucho tiempo hemos hecho de Roma la mayor de las ciudades vecinas, sirviéndonos de este sistema de gobierno que tú criticas. ${ }^{30}$

Por otro lado, para defender su propuesta de matrimonio entre patricios y plebeyos, Canuleyo remarcaba que los primeros estaban equivocados al insistir en que Roma había permanecido sin cambios. Varios reyes habían sido extranjeros, pero fueron elegidos debido a sus sobresalientes cualidades; del mismo modo, los monarcas habían establecido instituciones nuevas acordes con las circunstancias, mostrando una gran capacidad política. Después de los reyes se crearon los cónsules y otros magistrados debido a la necesidad de los tiempos. Según esta visión, la ciudad había estado abierta a los hombres virtuosos sin importar su origen; asimismo, los ancestros habían creado cosas nuevas porque eran provechosas y útiles. ${ }^{31}$ Canuleyo indicaba que su proceder era consecuente con la actitud de los mayores, por lo que, para reforzar sus innovaciones, utilizaba episodios escogidos del pasado romano.

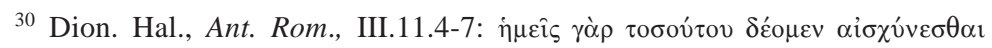

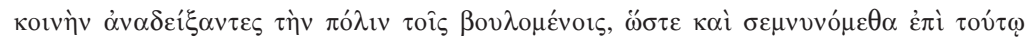

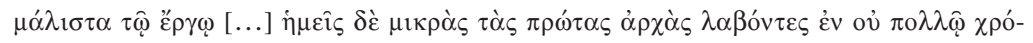

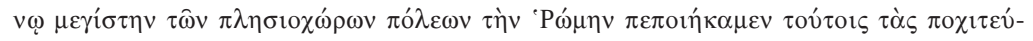

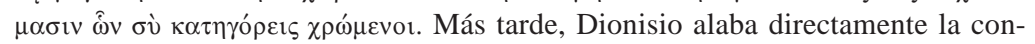
cesión de derechos por parte de Roma hacia los vencidos y la contrasta con la postura cerrada de las ciudades griegas. Idem, XIV.6. Asilo de Rómulo: idem, II.15.3-4, y Liv., I.8.

${ }^{31}$ Idem, IV.3-4.
} 

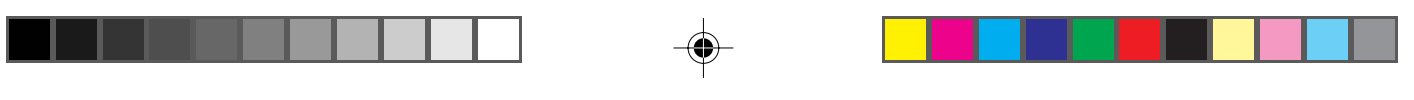

LA ACTITUD ROMANA ANTE EL PASADO / Noua tellus, 25•2, 2007, pp. 231-272

Otro personaje que recurrió a esta postura fue Julio César. Su posición abierta a los cambios se plasmó en numerosas reformas en diversos campos, lo que en muchas ocasiones chocaba con las suspicacias del grupo tradicionalista del orden senatorial que veía en sus medidas un intento de destruir el sistema republicano, halló su defensa en la historia romana. Ante el senado, Julio César aducía que los romanos habían tomado las insignias de los magistrados de los etruscos y las armas ofensivas y defensivas de los samnitas, por ello sostenía que la asimilación de elementos y hábitos extranjeros fue una práctica usual entre los antiguos romanos, quienes no temían cambiar para mejorar, ya que

nunca carecieron de sensatez e iniciativas, ni era tanta su soberbia que les impidiese imitar las instituciones extranjeras, con tal de que fuesen buenas [...] cuanto por doquier parecíales idóneo entre los enemigos y aliados, introducíanlo en su patria con la mayor diligencia, prefiriendo más imitar los buenos ejemplos que envidiarlos..$^{32}$

A diferencia de quienes decían que Roma se definía por el afecto a lo establecido, Julio César hacía de la admisión de lo ajeno, siempre que fuera bueno y útil, un rasgo típico romano y lo que distinguía a la historia romana, por lo que apelaba a los hábitos de los antepasados para justificar su propia posición. Una situación similar aconteció con la manera en que el emperador Claudio defendió su propuesta de incluir a los galos en el senado. Alegaba que esto no era desconocido en la historia romana, determinada por su gran apertura a los forasteros: su antepasado más antiguo fue admitido como ciudadano y patricio al igual que muchas otras familias provenientes

\footnotetext{
${ }^{32}$ Sall., Cat., LI.37-38: neque consili neque audaciae umquam eguere, neque illis superbia obstabat quo minus aliena instituta, si modo proba erant, imitarentur [...] quod ubique apud socios aut hostis idoneum uidebatur, cum summo studio domi exsequebantur; imitari quam inuidere bonis malebant.
} 

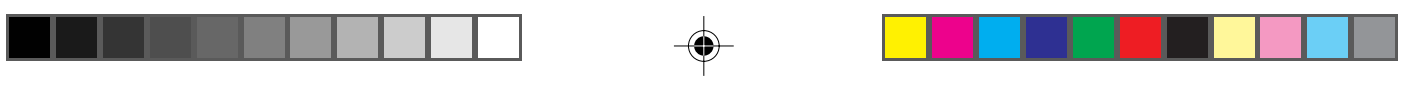

de fuera. Estos precedentes le pedían congruencia con el pasado romano y "emplear sus mismas pautas en los asuntos del Estado, trasladando hasta aquí lo que alguna vez haya sido digno de reseñar". ${ }^{33}$ Claudio insistía en que sus acciones no eran innovaciones, sino una vuelta a los hábitos antiguos que habían mostrado su eficacia, a los que él se apegaba. Si bien reconocía que los galos habían sido enemigos de los romanos, también lo habían sido volscos, ecuos, etruscos y samnitas, lo que no evitó la asimilación de todos estos pueblos y su participación en los asuntos romanos. El príncipe que había escrito obras históricas y que fue alentado por Tito Livio en esta labor, recalcaba que su proceder se sustentaba en la historia romana y en las acciones de los antepasados, por eso acababa su discurso con una reflexión que ponía al pasado como marco de referencia en lugar de ser un molde rígido en que el presente era trazado:

Senadores, todo cuanto ahora se tiene por muy antiguo, fue una vez nuevo: los magistrados plebeyos después de los patricios, los latinos después de los plebeyos, los pertenecientes a los demás pueblos de Italia después de los latinos. Esto de ahora también envejecerá, y lo que defendemos ahora con ejemplos, se contará alguna vez entre esos ejemplos. ${ }^{34}$

Este pensamiento se reforzó con la insistencia en que el proceder típico romano era cambiar para mejorar. Sus propulsores señalaban que la realidad romana no fue estática y an-

\footnotetext{
${ }^{33}$ Tac., Ann., XI.24: uti paribus consiliis in re publica capessenda, transferendo huc quod usquam egregium fuerit.

${ }^{34}$ Loc. cit.: omnia, patres conscripti, quae nunc vetustissima creduntur, nova fuere: plebeii magistratus post patricios, Latino post plebeios, ceterorum Italiae gentium post Latinos. inveterascet hoc quoque, et quod hodie exemplis tuemur, inter exempla erit. Igualmente cuando Claudio dio la laticlavia al hijo de un liberto, no sin antes hacerlo adoptar por un caballero, para afrontar los reproches que sabía que iban a dirigirle, justificó su decisión aludiendo al ejemplo de su ancestro Apio Claudio que había hecho ingresar a hijos de libertos al senado. Suet., Claud., XXIV. Para un análisis de la política de Claudio de conceder la ciudadanía y privilegios a otros grupos, vid. Sherwin-White, op. cit., pp. 337-350.
} 

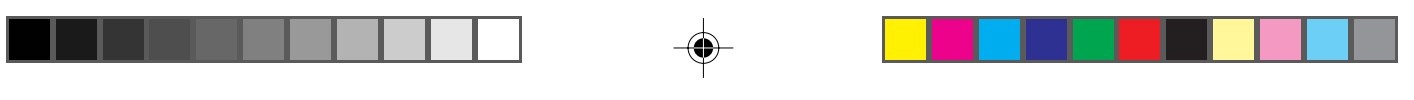

LA ACTITUD ROMANA ANTE EL PASADO / Noua tellus, 25•2, 2007, pp. 231-272

clada al pasado de una manera que la asfixiara, sino que los mayores habían actuado de acuerdo con las circunstancias, buscando siempre obtener un estado óptimo. Debido a esto, aquéllos vieron en la historia romana una justificación para sus propias medidas y una lección de conducta. Con motivo de la victoria romana sobre los latinos en el siglo IV a. C., los romanos afrontaron la decisión de cómo tratar a los vencidos. Lucio Camilo afirmaba que podían tratarlos con severidad y aniquilarlos, privándose de la posibilidad de aprovechar sus fuerzas, o imitar la conducta de los ancestros e incorporar a los latinos dentro del marco político romano y así incrementar la fuerza del Estado romano con nuevos ciudadanos y soldados. ${ }^{35}$ Claudio tuvo una meditación parecida en su discurso sobre la admisión de los galos al senado. Argumentaba que una vez concedida la ciudadanía romana a provinciales, éstos aportaron sus virtudes y vigor al servicio de la causa romana, dando varias y valiosas muestras de fidelidad y apego a Roma como cualquier otro nacido en los límites de la Ciudad. Esta acción aseguraba la continuidad de la hegemonía romana y era producto de las enseñanzas tanto de la historia de Roma como de otros pueblos, lo que lo llevó a preguntar:

¿Por qué otra razón se produjo la perdición de los lacedemonios y de los atenienses a pesar de su potencial en armas, sino por mantener a los vencidos apartados como si fueran extranjeros? Nuestro fundador Rómulo fue tan inteligente que a muchos pueblos, en el mismo día, les consideró como enemigos y luego como ciudadanos. ${ }^{36}$

\footnotetext{
${ }^{35}$ Liv., VIII.13. Tomando como ejemplo al ejército romano de su tiempo, Po-

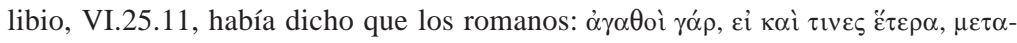

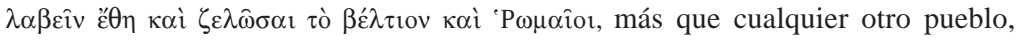
cambian fácilmente sus costumbres e imitan lo que es mejor que lo suyo.

36 Tac., Ann., XI.24: quid aliud exitio Lacedaemonis et Atheniensibus fuit, quamquam armis pollerent, nisi quod victos pro alienigenis arcebant? at conditor nostri Romulus tantum sapientia volvit ut plerosque populus eodem die hostis dein civis habuerit.
} 

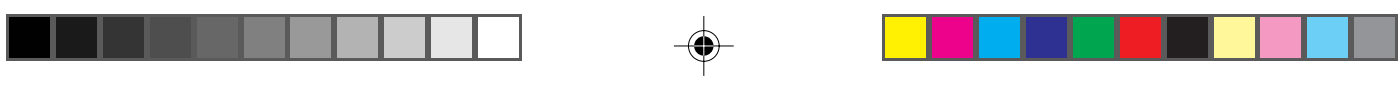

Tácito reconocía, frente a la vieja aristocracia senatorial, señalada por sus vicios, las virtudes y potencialidades de quienes provenían de colonias, municipios y provincias que fortalecían los órdenes con los valores de esfuerzo y trabajo, dando "la sobriedad de su origen y, aunque por la fortuna o por sus propios méritos llegaron ricos a la vejez, con todo permaneció en ellos el espíritu del principio". ${ }^{37}$ En contraste con tal actitud, se objetaba la adopción de hábitos extranjeros, considerados nocivos al ir en contra de las virtudes romanas. Esto es visible respecto a la adopción del ceremonial persa, acelerado a partir del siglo III d. C., ya que se creía que establecía un abismo injustificado entre el gobernante y los otros. Los lujos de la corte ocasionaban la debilidad del espíritu, incapacitaban al emperador para realizar sus deberes mediante su aislamiento y hacían que los cortesanos fueran los más beneficiados con las intrigas palaciegas. Además, la influencia persa ocasionaba que el soberano tratara despóticamente a los demás, asemejándose a la relación de un amo con un esclavo, esto era normal para los bárbaros, pero no para los romanos. Por ello se apelaba a la vuelta a las viejas tradiciones que habían fortalecido a Roma, criticando estas prácticas que se veían ajenas a los ideales republicanos y a los valores aristocráticos que compartían varios autores. ${ }^{38}$

\footnotetext{
${ }^{37}$ Idem, III.55: domesticam parsimoniam intulerunt, et quamquam fortuna vel industria plerique pecuniosam ad senectam pervenirent, mansit tamen prior animus. Siglos después, Aurelio Víctor, africano de origen humilde que había ascendido gracias a su educación, también reconocía el aporte de los extranjeros a la gloria de Roma. Con motivo de la toma del poder por los provinciales con Trajano, afirmaba que algunos príncipes originarios de las provincias fueron mejores que los nacidos en Roma. Señala: Ac mihi quidem audienti multa legentique, plane compertum urbem Romam externonum virtute atque insituiuis artibus praecipue creuisse, al menos para mí; que he oído y leído muchas cosas, es totalmente claro que la ciudad de Roma creció especialmente gracias a la valía de los extranjeros y a los talentos importados (Aur. Vic., Caes., 11.13). Las citas latinas de esta obra provienen de la Collection des Universités de France y las españolas de la Biblioteca Clásica Gredos.

38 Amm. Marc., 22.4. SHA, Gord., 23.7. Sinesio de Cirene, Al emperador. Sobre la realeza, 14a-18b. Claud., In Eutropium, 415.
} 

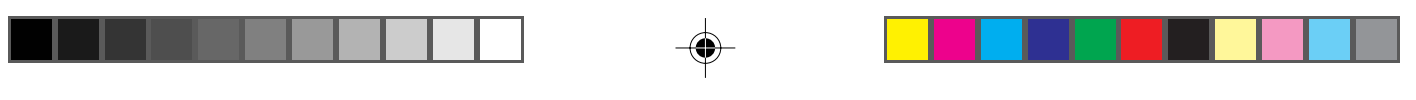

LA ACTITUD ROMANA ANTE EL PASADO / Noua tellus, 25•2, 2007, pp. 231-272

Esta dinámica estuvo relacionada con la incorporación de las élites de acuerdo con la conquista romana: primero los itálicos conforme a las distintas modalidades con que Roma los asoció a su dominio, estableciendo derechos y obligaciones. Aunque los tratados podían diferir, una obligación fundamental fue el aporte militar que resultó vital para las conquistas romanas; así Roma usaba los recursos de los aliados en sus empresas de expansión sin aplicarles tributos directos, atándolos en tiempos de guerra y haciendo menos opresiva su dominación en tiempo de paz. La organización política y social parecida entre Roma y otras ciudades facilitó este proceso, ya que los grupos dirigentes itálicos compartían intereses con los romanos, por lo que la cooperación con el vencedor era la mejor manera de adaptarse al nuevo escenario y de conservar una buena posición, pues se sabía que Roma recompensaba a quienes eran leales a ella. ${ }^{39}$

La comunión de intereses y la fortaleza de las alianzas, lo que también habla del buen trabajo realizado por los romanos, se vio en las pocas defecciones contra Roma durante los momentos más críticos de la guerra contra Aníbal, pues existía el convencimiento de que su situación era mejor con Roma, de lo que sería bajo el dominio de Cartago. Esta actuación se trasladó a los provinciales, no sin antes haber cometido abusos y errores, procurando atraer a los principales de las ciudades al concederles la ciudadanía y confirmar su autoridad. Los provinciales favorecidos se ocupaban de mantener la paz en las ciudades, de que no surgieran amenazas contra el poder romano y de la recauda-

\footnotetext{
${ }^{39}$ Cornell explica la lealtad de los aliados debido a que las aristocracias locales recurrían a Roma cuando sus intereses se veían amenazados, por ello los grupos prorromanos eran los más firmes colaboradores de Roma, asegurando su lealtad en tiempo de crisis. Además, obtenían parte de los botines de guerra en forma de bienes y tierras para colonización y para propiedad individual. Op. cit., pp. 418-421. Para un comentario sobre la forma en que la concesión de la ciudadanía romana y de privilegios económicos a los aliados tuvieron un papel definitorio en la preservación del poder romano y en la unificación de Italia con Roma, vid. Sherwin-White, art. cit., pp. 122-128. Alföldy, op. cit., pp. 47-48.
} 

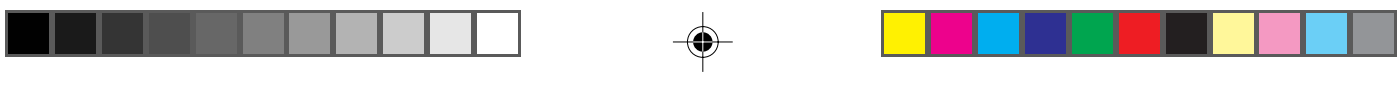

ción de tributo, lo que hacía posible un control más eficiente del Imperio. El principado fue una etapa crucial para esta evolución al mitigar la opresión de las provincias, pues las élites urbanas fueron los sostenes más firmes del régimen romano y de sus principales beneficiarias, esto llevó a Elio Arístides a decir en la etapa antonina que los romanos no tenían necesidad alguna de guarniciones que vigilaran las ciudades, ya que las personas más importantes y poderosas de éstas guardaban el orden en el nombre de Roma. ${ }^{40}$ Tal hecho, aunado a factores como la paz, el culto imperial y la participación política de los provinciales en la administración imperial, hizo que surgiera y se reafirmara el sentido de unidad de estos grupos privilegiados en torno a Roma, lo cual se tradujo en varios campos, y ayudó a lograr una importante cohesión política e ideológica.

En los siglos II y III Elio Arístides y Dion Casio, dos representantes de los grupos cultos y favorecidos por el Imperio, afirmaban que la atracción de las élites había sido una táctica romana y usaron la misma imagen para simbolizar esta sensación de unidad: para los provinciales Roma tenía la misma función con respecto a sus lugares de origen que el de una ciudad con sus campos circundantes. ${ }^{41}$ La asimilación de per-

\footnotetext{
${ }^{40}$ Aristid., Or., XXVI.64. Para la relación de Roma con las élites griegas en distintas fases vid. G. E. M. de Ste. Croix, La lucha de clases en el mundo griego antiguo, pp. 360-382 y 606-633. John Briscoe, "Roma y la lucha de clases en los Estados griegos, 200-146 a. d. C.”, en M. I. Finley (ed.), Estudios de Historia Antigua, pp. 65-85.

${ }^{41}$ Aristid., Or., XXVI.61. Dio Cass., LII.19.3. Hay estudiosos que insisten en que este proceso de adaptación no fue totalmente lineal e impuesto, pues no siempre el gobierno romano contaba con los medios o la voluntad para imponer sus políticas, sino que los grupos sometidos adoptaron y adaptaron los rasgos más útiles y próximos que Roma les brindaba de acuerdo con las necesidades y circunstancias para ligar sus tradiciones con la romana. Asimismo este desarrollo no fue unilateral, ya que la lengua, el arte, las instituciones y otros rasgos de los vencedores se conjugaron con elementos locales, lo que tampoco estuvo exento de conflictos. Keith Hopkins, "La Romanización: asimilación, cambio y resistencia", en Jaime Alvar y José María Blázquez (eds.), La Romanización en Occidente, pp. 1522. Richard Miles, "Communicating culture, identity and power", y Huskinson, "Elite culture and the identity of empire", pp. 52-59 y 107-116.
} 

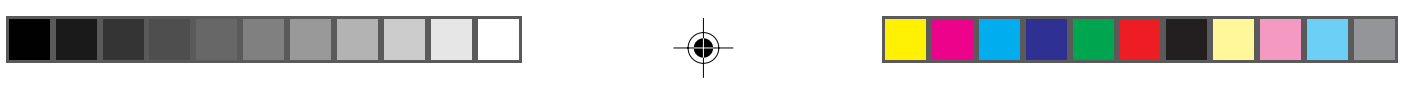

LA ACTITUD ROMANA ANTE EL PASADO / Noua tellus, 25•2, 2007, pp. 231-272

sonas, instituciones y costumbres fue crucial para el crecimiento de Roma, siendo una razón para los defensores del cambio y la inclusión por ser consecuentes con el antiguo modo de actuar romano.

La relación entre cambio y continuidad pareciera que enfrentaba a dos grupos antagónicos que eran consecuentes con sus propuestas y que rechazaban completamente la opuesta, pero los romanos no lo vieron de esta manera. En la mentalidad romana se dio una curiosa combinación de ambos elementos que hacía que no se percibiera este hecho como una contradicción insalvable o como causa de conflictos entre los autores. La mezcla de estos elementos se atribuyó a los primeros tiempos republicanos. Dionisio de Halicarnaso escribía que, ante la disyuntiva de elegir el gobierno ideal tras la expulsión de Tarquinio el Soberbio, Bruto sugirió cambiar el nombre y no el sistema para hacerlo aceptable y moderado. Además, recogía el ejemplo de otros pueblos: el poder colegiado de Esparta y el gobierno anual de Atenas para conservar las bondades de la monarquía y evitar sus riesgos y excesos. ${ }^{42}$

Una situación similar pasó con la institución regia como tal, para que el nombre real sancionado por los auspicios divinos que había acompañado a Roma desde su fundación se mantuviera por su carácter sacro, se nombró un rex sacrorum, lo cual también obedeció a evitar cualquier deseo de la realeza debido a escrúpulos religiosos. ${ }^{43}$ Tal percepción del gobierno

\footnotetext{
${ }^{42}$ Dion. Hal., Ant. Rom., IV.73-74. Igualmente, al hablar sobre la supuesta admisión de libertos como ciudadanos en tiempo de Servio Tulio, Dionisio exculpa a quienes lo aceptaron de abandonar las normas tradicionales sin razón. También indica que, después de cambiar esto, los romanos habían seguido liberando a los esclavos y dando la ciudadanía como una costumbre inamovible. Idem, IV.23-24.

${ }^{43}$ Idem, IV.73-74. Liv., II.2.
} 

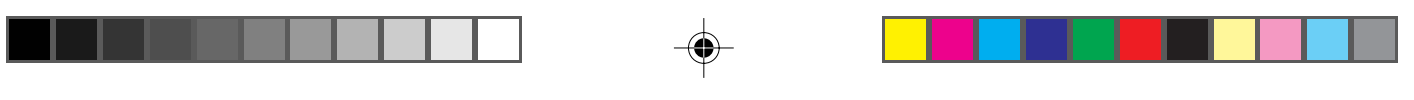

y sus instituciones es recogida por Cicerón. Éste presenta al gobierno romano como una herencia que los contemporáneos recibieron y conservaron como les fue entregada por sus padres y éstos de sus ancestros en una línea ininterrumpida de estricto apego al pasado, por lo que no había otro sistema que pudiera competir con ella. Sin embargo, esta línea de pensamiento se muestra al lado de otra que recuerda que un rasgo del gobierno romano que lo hacía el mejor es que no fue producto de un solo hombre, sino que se formó con el tiempo y tomando lo mejor de otros ejemplos. Los libros II y III de De la república son una síntesis de las aportaciones que diversos hombres hicieron en las fases monárquica y republicana para llegar al perfeccionamiento de la constitución romana. En boca de Escipión, el arpinate dice:

la sapiencia de nuestros mayores debe ser alabada por esto mismo: porque entenderás que inclusive muchas cosas que fueron tomadas de otra parte se hicieron entre nosotros mucho mejores de lo que habían sido allá de donde fueron trasladadas acá y donde surgieron por primera vez. ${ }^{44}$

El respeto a un pasado visto como legado y la afirmación de que la adopción de elementos externos había mejorado y enriquecido lo heredado, conviven sin que se vea el menor conflicto entre ambas posiciones. Hasta donde se conservó el tratado, no hay intento de aclarar estas afirmaciones que pudieran sugerir una contradicción entre una visión que sostenía el acatamiento de algo perfectamente establecido y otra que indicaba que el gobierno romano fue el resultado de continuos cambios y aportaciones realizadas a través del tiempo, conforme a los sucesos, lo que daba pie a nuevas modificaciones del sistema, en vez de apelar al seguimiento de un gobierno que

\footnotetext{
${ }^{44}$ Cic., Rep., II.30: quin hoc ipso sapientiam maiorum statues esse laudandam, quod multa intelleges etiam aliunde sumpta meliora apud non multo esse facta, quam ibi fuissent, unde huc translata essent atque ubi primum existitissent.
} 

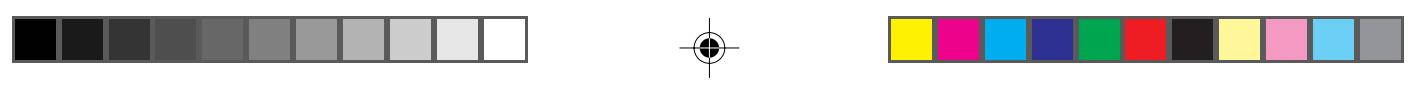

LA ACTITUD ROMANA ANTE EL PASADO / Noua tellus, 25•2, 2007, pp. 231-272

se había entregado de una vez y para siempre. Tal situación no es vista como conflictiva, ni estas posiciones aparecen contrapuestas.

Esta relación peculiar entre innovación y continuación también se reflejó en la conducta política de insignes personajes. Conocedor de que el pueblo romano tenía una vena profundamente tradicionalista y reacia a los cambios radicales, el tribuno Tiberio Graco se asoció con personalidades reconocidas y prestigiadas de la sociedad romana y presentó su reforma agraria como una vuelta al pasado al apelar a la ampliación de las leyes Licinias-Sextias. ${ }^{45}$ Esto lo hacía buscando la restitución de la pequeña propiedad, pues estaba convencido de que los forjadores de las viejas virtudes romanas y de los logros militares fueron los campesinos propietarios que se veían amenazados por la pérdida de sus tierras a manos de los latifundistas debido a sus años de servicio militar, engrosando la masa proletaria, lo que ocasionaba serios desequilibrios sociales que hacían peligrar la estabilidad republicana. Tiberio Graco era un gran admirador de la historia romana que no dudó en propulsar reformas y usar métodos innovadores ante el proceder intransigente de sus opositores para intentar regresar al antiguo estado de cosas.

Julio César fue otro personaje que pasó de un territorio a otro con extrema facilidad. Su orgullo aristocrático lo hacía presumir su ascendencia regia y divina por parte de Anco Marcio y Venus respectivamente en el discurso pronunciado en honor de su tía Julia; además de su insistencia en seguir oficialmente las leyes y formas tradicionales y de ejercer las magistraturas aunque con un sentido nuevo. Esto fue de la mano con su manera de atraerse el favor popular mediante el gasto en edificaciones y espectáculos, la concesión generosa de la ciudadanía romana, el uso de sus tropas para conseguir sus objetivos, etcétera. Sin embargo, su descuido de las formas republicanas

${ }^{45}$ Plut., Vit. T. Gracch., VIII-IX. 

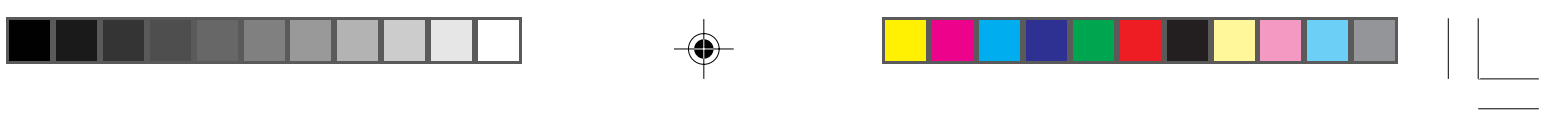

y su insistencia en concentrar el poder en su persona se empalmó con expresiones arrogantes que se le imputaban como "la república no era nada, una palabra sin cuerpo ni forma. Sila no conocía las letras porque depuso la dictadura. Los hombres debían ser más considerados al hablarle y tener lo que dijera como leyes". ${ }^{46}$ La actitud despectiva y altiva frente a otros magistrados y ante el senado lo llevó a realizar actos públicos inducidos para sondear el ánimo sobre la posibilidad de que fuera rey. En una sociedad educada en el odio a la realeza y con un orden senatorial lo suficientemente fuerte para oponer resistencia, el carácter y las acciones de Julio César chocaron contra varios escrúpulos.

Octavio no cometería el mismo error que su tío. De talante mesurado, se mostró respetuoso con las formas republicanas y asumió oficialmente su restauración gracias a que puso cuidado en recalcar las diferencias entre los órdenes para mantener la distinción del orden senatorial. A la par, estas acciones fueron acompañadas por contención del otorgamiento de la ciudadanía romana y la divulgación de un regreso a las costumbres, los cultos y la moralidad de los viejos tiempos. Empero, también concentró el poder al asumir diversas magistraturas al mismo tiempo para usar sus principales atribuciones como el mando de tropas y la potestad tribunicia, lo que dio como resultado que el principado fuera una monarquía con disfraz republicano. ${ }^{47}$

\footnotetext{
${ }^{46}$ Suet., Iul., LXXVII: nihil essem rem publicam, appellationem modo sine corpore ac species. Sulla nescisse litteras, qui dictaturam deposuerit. Debere homines consideratius iam loqui secum ac pro legibus habere quae dicat. La cita latina de esta obra proviene de la Loeb Classical Library. El recelo contra Julio César provenía de la nobleza, aunque Suetonio señale en un pasaje que había disgusto popular por su actitud (Iul., LXXX). También Eutropio indicaba que Julio César actuó insolentemente contra la libertad romana (VI.26.5). En todo caso hay una presencia aplastante de referencias sobre su popularidad ante el pueblo y con los provinciales.

${ }^{47}$ Augusto insistió en que no aceptó títulos y cargos que se le ofrecían por ser contrarios a las costumbres antiguas (RGDA, 6. Suet., Aug., X, LII, LIII). Igualmente Agustín creía que Augusto había renovado la república al conservar la
} 

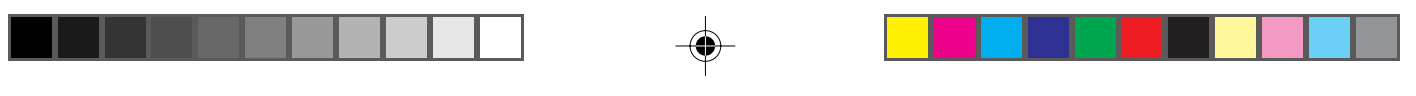

LA ACTITUD ROMANA ANTE EL PASADO / Noua tellus, 25•2, 2007, pp. 231-272

Augusto no vio una contradicción insuperable al presentarse como restaurador y reformador a la vez. De carácter conservador, intentó mantener las costumbres patrias y únicamente cambiar aquello que fuera necesario para asegurarse el poder de manera estable, sin tocar lo que no era necesario. Siendo un gran genio político, aprovechó las condiciones de su tiempo y tuvo buen éxito en consolidar su gobierno y difundir su imagen como lo deseaba. Aunque revistiera las magistraturas con un matiz nuevo para adecuarlas a sus deseos y a las nuevas condiciones imperantes, en su testamento político aclara que no hizo acción alguna en contra de la tradición. Augusto afirma que con "leyes nuevas de mi autoría restauré muchos ejemplos de los mayores caídos en desuso en nuestra época y yo mismo transmití el ejemplo de muchas cosas para ser imitadas por la posteridad". ${ }^{48}$ Nuevas leyes, restauración de viejas costumbres y forjar precedentes son ideas que convivieron sin que crearan conflictos infranqueables en los hombres de este periodo acostumbrados a que tradición e innovación estuvieran presentes en la sociedad romana.

Esta situación explica que el régimen personal estaba plenamente afianzado y era claro que el regreso a la república no era posible ni deseable en términos reales, Apiano señaló tanto el respeto formal del principado a los modos republicanos como su efectivo carácter al decir:

libertad y sólo quitar sus efectos perniciosos, aunque no la restableció como los senadores deseaban (De Civ. D., III.21, 30). Tácito obviamente reprobaba esto (Ann., I.2-3). Sobre el carácter y la función de Augusto, vid. Ronald Syme, La revolución romana, pp. 18-24.

${ }^{48}$ RGDA, 8: Legibus nouis me auctore latis multa exempla maiorum exolescentia iam ex nostro saeculo reduxi et ipse multarum rerum exempla imitanda posteris tradidi. La cita latina de esta obra proviene de la Collection des Universités de France. También Suetonio ve a Augusto como restaurador y conservador (Suet., Aug., XXIV, XXVI, XXXII y XXXIV). Para un análisis de la política y mentalidad de Augusto como la adopción parcial de ideas extranjeras y la preeminencia de los elementos romanos para conservar los rasgos romanos del Imperio frente a la tendencia oriental de Marco Antonio, vid. Lidia Storoni Mazzolani, The idea of the city in Roman thought. From walled city to spiritual commonwealth, pp. 126-150. 

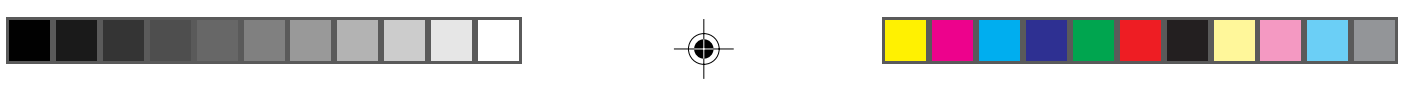

su forma de gobierno ha sido, hasta el presente, una monarquía a cuyos gobernantes no llaman reyes, según creo, por respeto al antiguo juramento, sino que los designan con el nombre de emperadores, que también era el nombre de los comandantes en jefe durante el tiempo de su mando, pero, de hecho, son reyes en todo. ${ }^{49}$

Este modo de afrontar cambio y tradición también se reflejó en Diocleciano, quien se creía el restaurador del orden romano y el continuador de las viejas hazañas militares de Roma y de las virtudes de valor y trabajo, aunque también desarrolló reformas que igualaron a Italia con las provincias en la administración y eliminó los últimos rastros republicanos al impulsar el ceremonial oriental. ${ }^{50}$ Igualmente, Juliano se veía a sí mismo como el preservador de los viejos cultos, despidió a cortesanos y eunucos, buscó imitar las gestas militares frente a los enemigos de Roma y seguir las pautas tradicionales de respeto a las leyes. Debido a esto, según Amiano, "maltrató la memoria de Constantino como renovador y agitador de las leyes antiguas y de las costumbres antiguamente recibidas". ${ }^{51}$ Sin em-

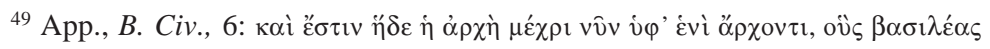

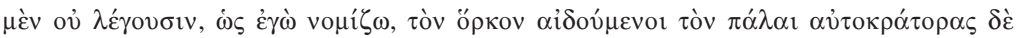

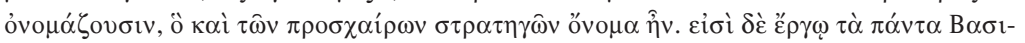
$\lambda \varepsilon i \hat{c}$. La cita griega de esta obra proviene de la Loeb Classical Library y la española de la Biblioteca Clásica Gredos. Una anotación similar en Sinesio, Sobre la realeza, 19b. Sobre el carácter del principado vid. Ste. Croix, op. cit., pp. 435457. Kunkel, op. cit., pp. 55-67.

${ }^{50}$ Aunque reconocían sus cualidades como gobernante y militar, algunos autores critican el desarrollo de la corte bajo su gobierno con la postración y los adornos excesivos (Eutr., IX.26, y Aur. Vict., Caes., 39.1-4).

${ }^{51}$ Amm. Marc., 21.10.8: Tunc et memoriam Constantini, ut novatoris turbatorisque priscorum legum et mores antiquitus recepti, vexavit. Para Eusebio, el proceder de Constantino fue distinto, ya que, mientras Licinio abolió las viejas leyes romanas, sabiamente asentadas y las sustituyó por otras despiadadas y bárbaras, Constantino buscó renovarlas y transformarlas con el fin de que fuesen mejores (Euseb., Vit. Const., I.55.1 y IV.26.1). Aun en el siglo VI, Procopio acusa a Justiniano de confundir todo al introducir cambios y suprimir las antiguas costumbres en leyes, cargos públicos y administración por el mero afán de cambiar (Procop., Arc., XI.1-2). 

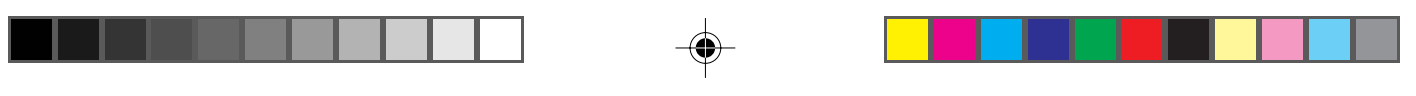

LA ACTITUD ROMANA ANTE EL PASADO / Noua tellus, 25•2, 2007, pp. 231-272

bargo, no evitó ser llamado Señor y que pensara que estaba privilegiando a quien besara su manto.

Asimismo, la aristocracia senatorial vivió el fenómeno en que se encontraban tradición e innovación. A pesar de su constante adopción de nuevos miembros a través de los siglos, se presentó como un cuerpo cerrado que no había tenido modificaciones en su seno. Como guardián de las viejas tradiciones tuvo bastante éxito al imponer sus valores a los demás estratos sociales, sabiendo que estaba en lo más alto de la pirámide social, contando con recursos económicos, educación, contactos políticos e influencias. Aunque los espacios políticos le fueron cerrados por emperadores como algunos Julio-Claudios que elegían a libertos para puestos importantes, Adriano a caballeros, y que Galieno y Diocleciano evitaron que ejercieran puestos civiles y militares, exceptuando algunos, su posición social no sufrió menoscabo. Su prestigio era evidente cuando advenedizos eran recompensados con el acceso al orden senatorial; además, príncipes no nobles ingresaron a la aristocracia y les procuraron a sus hijos una buena educación, siendo una manera de ascender socialmente, lo que fue frecuente al surgir hombres de origen humilde provenientes del ejército que vestían la púrpura imperial a partir del siglo III. ${ }^{52}$ Esta educación estaba moldeada en los valores de la nobleza, pues era forjada y enseñada por sus miembros o por personas afines ideológicamente, lo que la convertía en una excelente vía de promoción de sus ideales y formas. De este modo, los recién llegados les aseguraban a sus herederos la instrucción y los medios necesarios para poder equipararse a la vieja nobleza, provocando

\footnotetext{
52 Tales fueron los casos de Didio Juliano y Macrino que ingresaron a la nobleza al asumir el imperio, mientras que Maximino Tracio le proporcionó a su hijo la mejor educación disponible, lo que distinguía claramente al rudo padre del hijo cultivado (SHA, Did. Jul., 3.4; Macr., 7.1; Max., 27.3-5). Un comentario sobre el orden senatorial después del siglo III y su recomposición bajo Constantino, en Alföldy, op. cit., pp. 256-263, y Perry Anderson, Transiciones de la antigüedad al feudalismo, pp. 98-100.
} 

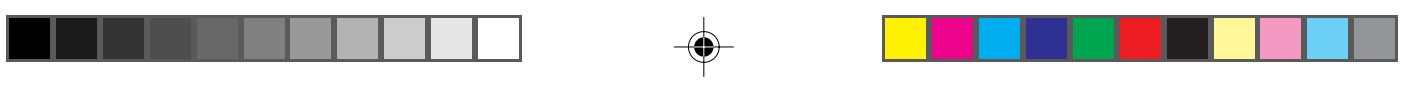

también que fueran algunos de los mejores exponentes de la moral aristocrática. La educación se convirtió en un excelente medio de promoción y distinción para quienes escalaban a posiciones de poder y era un factor aristocratizante que unía a los hombres nuevos con los nobles de abolengo que gozaban de esta formación. Un ejemplo fue Aurelio Víctor, quien había llegado a una posición privilegiada desde un origen modesto, gracias a su preparación y a su desempeño en la burocracia imperial. Su acceso a los altos círculos de su época lo llevó a decir:

los más humildes, especialmente cuando llegan a los altos cargos, no tienen mesura en su soberbia y ambición [...] Por esto me asombra que la mayoría acuse de soberbia a la nobleza, la cual recordando sus orígenes patricios, tiene algún derecho a sobresalir un poco como compensación de las molestias con las que es abrumada. ${ }^{53}$

A pesar de los diversos orígenes de sus miembros, el orden senatorial de la Antigüedad tardía tenía grandes riquezas, la formación cultural y el sentido de grupo que los hacía conservar la visión de que era lo mejor de su sociedad de un modo que sus predecesores del siglo II a. C. no tendrían problema en admitir. El panegirista Nazario decía que Roma, la reina del mundo, vinculaba a los más nobles de las provincias en su

\footnotetext{
${ }^{53}$ Aur. Vic., Caes., 39.5-7: humillimos, quosque, maxime ubi alta accesserint, superbia atque ambitione immodicos esse [...] Quo mihi mirum videtur nobilitati plerique superbiam dare, quae gentis patriciae memor, molestiarum, quis agitatur, remedio eminere paululum pluris habet. No obstante, critica en otra cita la desidia de la nobleza (idem, 37.2-4). Hay varios pasajes donde expresa su elogio por la preparación intelectual, además de su aprobación de los emperadores que sobresalían por su educación y el reproche a los incultos (idem, 8.7-8, 22.2-5, 40.12-13 y 42.4). Eutropio hace observaciones similares (VII.7.21, VIII.7.2, X.7.2 y X.16.3). Ambos autores prestaron atención a tales temas porque debían su ascenso a estas cualidades; su asunción de los valores aristocráticos no fue algo raro. Sobre la movilidad social en esta etapa, vid. Keith Hopkins, "Movilidad de la élite en el Imperio Romano”, en Finley, op. cit., pp. 123-136.
} 

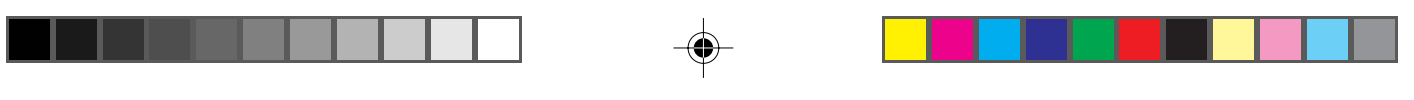

curia para que el senado reuniera a lo más selecto del orbe en su seno; Símaco estimaba al senado como la mejor agrupación del género humano; y Rutilio felicitaba a quienes tenían la fortuna de vivir en Roma y de participar en el senado, al que calificaba de curia religiosa, que acogía a lo mejor de los provinciales, asemejándolo al concilio del sumo dios ${ }^{54}$ Cameron indica que, no obstante los diferentes contextos históricos, nadie hubiera intentado desechar los modelos sociales existentes que beneficiaban al orden senatorial. De este modo, sus privilegios legales y los signos externos que afirmaban su posición fueron mantenidos e incluso realzados. ${ }^{55}$

El vínculo con la costumbre también pasaba por la apelación al hábito reciente que rivalizaba con el más antiguo. Tiberio recibió críticas por no rendir a Germánico las honras fúnebres dadas tradicionalmente a los nobles, además se sospechaba que había participado en su muerte. Ante esto sostenía que muchos romanos ilustres habían ofrendado sus vidas por la patria y que ninguno había suscitado reacciones tan exaltadas como la muerte de Germánico. También señalaba que el pueblo romano había llevado la pérdida de ejércitos, generales y familias nobles con gran entereza y moderación; asimismo, aseveraba seguir el ejemplo de Julio César, quien disimuló su tristeza por la muerte de su hija, y el de Augusto con sus nietos Cayo y Lucio. ${ }^{56}$

${ }^{54}$ Pan. Lat., X.35.2. Symmachus, Ep., I.52. Rut. Namat., I.7-18. Otros pasajes que muestran el orgullo aristocrático por su posición, especialmente de quienes presumían sus antiguos linajes, y los recelos de los advenedizos: Hdn., I.3.5, I.7.1-4 y II.3.1-4; Pan. Lat., VII.3.1, y Eutr., X.19.2. Empero, también hay evidencia que reconoce el mérito de quienes ascendían por su capacidad y mérito, los cuales mostraban su orgullo y, en ocasiones, críticas a la nobleza (Sall., Iug., LXXXV; Plut., Vit. Mar., 9.1; Hdn., V.1.5-7; Pan. Lat., III.3.9, y Aur. Vic., Caes., 39.27

${ }^{55}$ Cameron, op. cit., pp. 103-104.

56 Tac., Ann., III.6. Veyne indica que la costumbre ancestral era esgrimida como objeción, lo que significa que se le traía a colación cuando se había violado. Se usaba para contener las innovaciones, por lo que, para hacer frente a esto, 

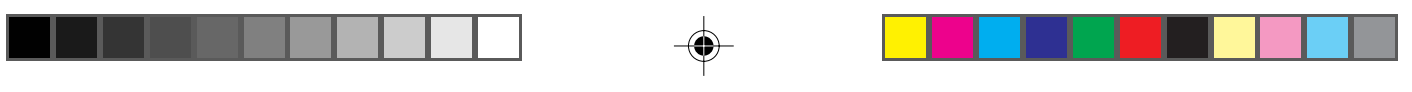

Aunque se tenía reverencia hacia el pasado, esto no llevaba a una actitud estática que impidiera la adquisición de otros elementos ni de desprecio por lo nuevo, sino que se aprovechaba lo viejo para avanzar. El reconocimiento del pasado no impedía que se admitieran los méritos del presente, ya que éste recoge lo que los antiguos han dejado de beneficioso y enmienda las cosas en que se han equivocado. Esta línea de pensamiento se deja ver en Tácito. Son comunes sus expresiones de alabanza hacia la libertad que asociaba a la república, lo que identifica con la libertad del senado, en contraste con el servilismo senatorial de su tiempo y la imposición de la voluntad de uno, así como su elogio hacia las virtudes y la moral de los viejos tiempos en una perspectiva que lo enlazaba con la aristocracia del senado. No obstante, no era alguien que vivía en el pasado cerrado a lo útil que el presente tenía, lo cual le hacía reconocer las propias cualidades de su época que habían producido hombres y acciones que también merecían recordarse y emularse. Exclamaba enfáticamente y sin rodeos que "no todo lo de nuestros antepasados es lo mejor, sino que también nuestra época ha dejado a la posteridad muchas glorias y artes dignas de imitar. Pues bien, ique dure esa competencia que tenemos con nuestros antepasados por las cosas honestas!"57

se apelaba al hábito actual igualmente válido, de modo que la tradición no tenía ninguna autoridad (Paul Veyne, "El imperio romano", en Philippe Ariés y Georges Duby (dir.), Historia de la vida privada, v. 1, p. 176). Empero, para no tener autoridad, la costumbre fue usualmente referida, lo que no tendría sentido, si no tuviera ningún peso o no se esperara obtener algo con ello, cosa improbable en una sociedad con una línea tradicionalista; si fuera el caso, ni siquiera se hubieran tomado la molestia de utilizarla.

${ }^{57}$ Tac., Ann., III.55: nec omnia apud priores meliora, sed nostra quoque aetas multa laudis et artium imitanda posteris tulit. Verum haec nobis in maiores certamina ex honesto maneant. Igualmente Séneca distingue el respeto a los antepasados, del que se declara partidario, del sometimiento servil a ellos. Se debe reverenciar y seguir a los ancestros, pero éstos dejaron muchas cosas por descubrir. Al igual que una herencia, debe aumentarse el conocimiento que los antiguos dejaron para las próximas generaciones; si solamente se estuviera satisfecho con lo legado, no se encontraría nada nuevo (Sen., Ep., XXXIII.10-11, XLIV.4, 

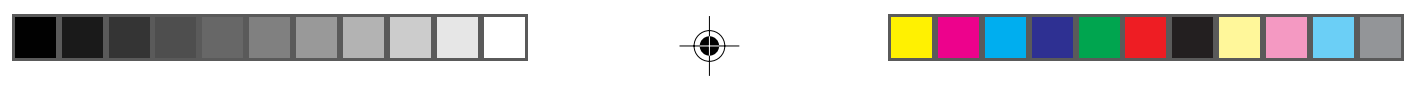

LA ACTITUD ROMANA ANTE EL PASADO / Noua tellus, 25•2, 2007, pp. 231-272

En esta visión se veneraba al pasado que debía ser preservado como un precioso legado recibido de los mayores, pero esto no implicaba que solamente se debía ser un receptor pasivo que se contentaba con tomar algo dado, sino que se debía tener una postura dinámica al recuperar los elementos provechosos del pasado y adoptar lo útil y lo nuevo que ofrecía el presente para mostrarse verdaderamente digno de los ancestros, al aumentar lo recibido y establecerse también a sí mismo como ejemplo para la siguiente generación. Es cierto que comúnmente cambio y costumbre aparecen en un clima de disputa en el que algún personaje proclama uno en oposición a otro, pero este hecho no necesariamente indica que un individuo abrazara una postura de forma intransigente. Se ha visto que algunos preferían algún rasgo sobre otro y se percibían como continuadores o innovadores, pero tenían una actitud flexible que les permitía usar ambos elementos sin renunciar a sus tendencias y sin percibir tal hecho como conflictivo o contradictorio. Los romanos tenían una vena tradicionalista que los hacía conservar y enorgullecerse de las costumbres e instituciones heredadas de sus antepasados debido a su antigüedad, pero también mostraron gran flexibilidad para adoptar nuevos elementos conforme a las circunstancias. Así, se sentían con total libertad de preservar y respetar lo antiguo, a la vez que eran capaces de introducir nuevas prácticas y modos, dando como resultado una peculiar interacción y convivencia entre tradición e innovación. Cuando se analiza la manera en que los romanos veían su pasado, usualmente se enfatiza un aspecto, sea el cambio o la permanencia, como si fueran excluyentes, lo que obedece al deseo del lector moderno de definir tajantemente su proceder respecto a este tema. No obstante, aunque con problemas, los romanos no fueron tan categóri-

LXIV.8-9 y LXXX.1). Acerca del modo en que esta visión se reflejaba en la literatura, vid. José Antonio Maravall, Antiguos y modernos. Visión de la historia e idea del progreso hasta el Renacimiento, pp. 125-133. 

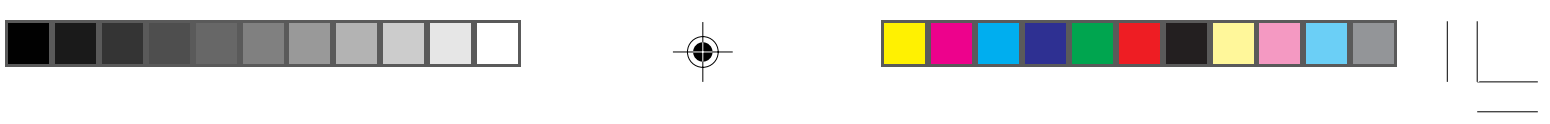

cos, sino que se valieron de ambos y no eligieron uno para excluir al otro, pues sabían que estos rasgos tenían cabida en su historia, a veces enfrentándose, otras influyéndose, pero aprovechándolos para sus propósitos.

\section{BIBLIOGRAFÍA}

\section{Fuentes antiguas}

Ammianus Marcellinus, I, trad., introd. y notas de John C. Rolfe, Londres y Cambridge, William Heinemann-Harvard University Press (The Loeb Classical Library), 1963 (3a. reimp.).

-, II, trad. y notas de John C. Rolfe, Londres y Cambridge, William Heinemann-Harvard University Press (The Loeb Classical Library), 1950.

Apiano, Historia Romana, I, trad., introd. y notas de Antonio Sánchez Royo, Madrid, Gredos (Biblioteca Clásica Gredos, 34), 1980.

Appian, Roman History, I, introd. y trad. de Horace White, Londres y Cambridge, William Heinemann-Harvard University Press (The Loeb Classical Library, 2), 1978 (1a. reimp.).

Augustine, The city of God against the pagans, I, trad., introd. y notas de George G. McCracken, Londres y Cambridge, William HeinemannHarvard University Press (The Loeb Classical Library, 411), 1963.

Aurelius Victor, Livre des Césars, texte établi et traduit par Pierre Dufraigne, París, Société d'Edition, "Les Belles Lettres" (Collection des Universités de France), 1975.

Cícerón, De la república, introd., vers. y notas de Julio Pimentel Álvarez, México, Universidad Nacional Autónoma de México-Instituto de Investigaciones Filológicas (Bibliotheca Scriptorum Graecorum et Romanorum Mexicana), 1984.

Claudian, I, trad. de Maurice Plautner, Londres y Cambridge, William Heinemann-Harvard University Press (The Loeb Classical Library, 135), 1956 (1a. reimp.).

Dio, Roman History, VI, trad. de Earnest Cary, Londres y Cambridge, William Heinemann-Harvard University Press (The Loeb Classical Library), 1955.

Dionisio de Halicarnaso, Historia antigua de Roma, I-III, introd. de Domingo Plácido, trad. y notas de Elvira Jiménez y Ester Sánchez, Madrid, Gredos (Biblioteca Clásica Gredos, 73), 1984. 

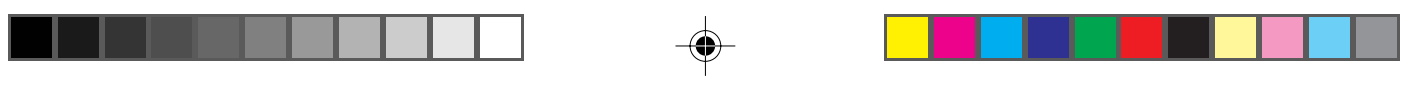

LA ACTITUD ROMANA ANTE EL PASADO / Noua tellus, 25•2, 2007, pp. 231-272

-, Historia antigua de Roma, IV-VI, trad. y notas de Almudena Alonso y Carmen Seco, Madrid, Gredos (Biblioteca Clásica Gredos, 74), 1984.

-, Historia antigua de Roma, X-XX, trad. y notas de Elvira Jiménez y Ester Sánchez, Madrid, Gredos (Biblioteca Clásica Gredos, 124), 1988.

Dionysius of Halicarnassus, Roman Antiquities, I, trad. introd y notas de Earnest Cary, Londres y Cambridge, William Heinemann-Harvard University Press (The Loeb Classical Library, 319), 1948 (1a. reimp.).

-, Roman Antiquities, II, trad. y notas de Earnest Cary, Londres y Cambridge, William Heinemann-Harvard University Press (The Loeb Classical Library, 320), 1953 (1a. reimp.).

Elio Arístides, Discursos, IV, trad., introd. y notas de Juan Manuel Cortés Copete, Madrid, Gredos (Biblioteca Clásica Gredos, 238), 1997.

Eusebio de Cesarea, Vida de Constantino, trad., introd. y notas de Martín Gurruchaga, Madrid, Gredos (Biblioteca Clásica Gredos, 190), 1994.

Eutropio, Breviario-Aurelio Víctor, Libro de los Césares, trad., introd. y notas de Emma Falque, Madrid, Gredos (Biblioteca Clásica Gredos, 261), 1999.

Herodiano, Historia del Imperio Romano después de Marco Aurelio, trad., introd. y notas de Juan J. Torres Esbarranch, Madrid, Gredos (Biblioteca Clásica Gredos, 80), 1985.

Historia Augusta, trad. e introd. de Vicente Picón y Antonio Cascón, Madrid, Akal (Akal Clásica, 16), 1989.

Panegiristas en Biógrafos y panegiristas latinos, introd. de Víctor José Herrera Llorente, Madrid, Aguilar, 1969.

Plutarch, Lives IX. Demetrius and Antony. Pyrrhus and Caius Marius, trad. y notas de Bernadatte Perrin, Londres y Cambridge, William Heinemann-Harvard University Press (The Loeb CLassical Library), 1968 (3a. reimp.).

Plutarco, Vite parallele. Lisandro e Silla, introd. de Luciano Canfora y Arthur Keaveney, trad. y notas de Federico María Muccioli y Lucía Ghilli, Milán, Rizzoli (BUR Classici Greci e Latini), 2001.

-, Vite Parallele. Agide Cleomene-Tiberio e Caio Gracco, trad., introd. y notas de Domenico Magnini, Milán, Rizzoli (BUR Classici Greci e Letini), 2001 (3a. ed.).

PoliBIO, Historia, V-XV, trad. y notas de Manuel Balasch Recort, Madrid, Gredos (Biblioteca Clásica Gredos, 43), 1981.

PolyBe, Histories, VI, texte établi et traduit par Raymond Weil y Claude Nicolet, París, Société d'Edition, "Les Belles Lettres" (Collection des Universités de France), 1977. 

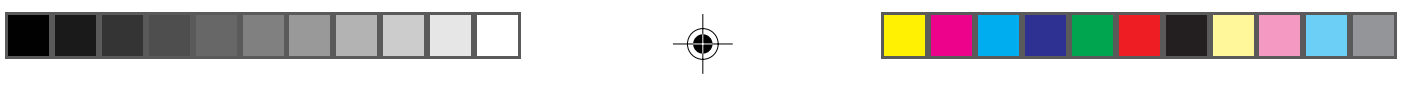

Procopio de Cesarea, Historia Secreta, trad., introd. y notas de Juan Signes Codoñer, Madrid, Gredos (Biblioteca Clásica Gredos, 279), 2000.

Res Gestae Divi Augusti, texte établi et commenté par Jean Gagé, París, Société d'Edition, "Les Belles Lettres" (Collection des Universités de France), 1977.

Rutilius Namatianus, De reditu suo, en Minor Latin Poets, trad. e introd. de J. Wight Duff y Arnold M. Duff, Londres y Cambridge, William Heinemann-Harvard University Press (The Loeb Classical Library), 1961 (3a. ed.).

SAlustio, Guerra de Yugurta-Fragmentos de las Historias-Cartas a César sobre el gobierno de la república, introd., trad. y notas de Agustín Millares Carlo, México, Universidad Nacional Autónoma de MéxicoCoordinación de Humanidades (Bibliotheca Scriptorum Graecorum et Romanorum Mexicana), 1998 (1a. reimp.).

-, La conjuración de Catilina, pról., vers. y notas de Agustín Millares Carlo, México, Universidad Nacional Autónoma de MéxicoCoordinación de Humanidades (Bibliotheca Scriptorum Graecorum et Romanorum Mexicana), 1984.

SÉneCA, Cartas Morales, I, trad., introd. y notas de José M. Gallegos Rocafull, México, Universidad Nacional Autónoma de México-Coordinación de Humanidades (Bibliotheca Scriptorum Graecorum et Romanorum Mexicana), 1951.

Símaco, Cartas, I-V, trad., introd. y notas de José Antonio Valdés Gallego, Madrid, Gredos (Biblioteca Clásica Gredos, 281), 2000.

Sinesio de Cirene, Himnos-Tratados, trad., introd. y notas de Francisco Antonio García Romero, Madrid, Gredos (Biblioteca Clásica Gredos, 186), 1993.

SuETonius, I, trad., introd. y notas de J. C. Rolfe, Londres y Cambridge, William Heinemann-Harvard University Press (The Loeb Classical Library), 1951 (5a. reimp.).

TÁCITO, Anales, trad., introd. y notas de Crescente López de Juan, Madrid, Alianza Editorial (El libro del bolsillo, 1652), 1993.

-, Annalium ab excessu divi Augusti libri, ed. crítica de C. D. Fischer, Oxford, Oxford University Press (Scriptorum Classicorum Bibliotheca Oxoniensis), 1981.

Tito Livio, Historia de Roma, I-III, introd. de Ángel Sierra, trad. y notas de José Antonio Villar Vidal, Madrid, Gredos (Biblioteca Clásica Gredos, 144), 1997 (1a. reimp.).

- Historia de Roma, IV-VI, trad. y notas de José Antonio Villar Vidal, Madrid, Gredos (Biblioteca Clásica Gredos, 145), 1990. 

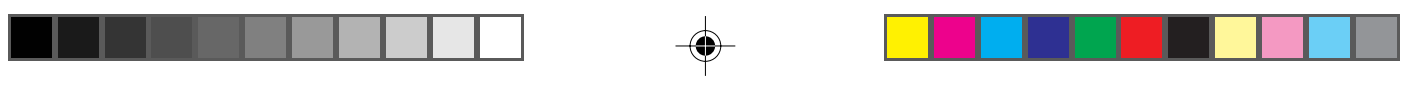

LA ACTITUD ROMANA ANTE EL PASADO / Noua tellus, 25•2, 2007, pp. 231-272

-, Historia de Roma, VIII-X, trad. y notas de José Antonio Villar Vidal, Madrid, Gredos (Biblioteca Clásica Gredos, 148), 1990.

—, Ab urbe condita, I-V, ed. crítica de Robertus Maxwell Ogilvie, Oxford, Oxford University Press (Scriptorum Classicorum Bibliotheca Oxoniensis), 1974.

—, Ab urbe condita, VI-X, ed. crítica de Carolus Flamstead Walters y Robertus Seymour Conway, Oxford, Oxford University Press (Scriptorum Classicorum Bibliotheca Oxoniensis), 1988.

\section{Fuentes modernas}

AlföLDY, Géza, Historia social de Roma, trad. de Víctor Alonso Troncoso, Madrid, Alianza Editorial (Alianza Editorial, 482), 1987.

Anderson, Perry, Transiciones de la antigüedad al feudalismo, trad. de Santos Julia, México, Siglo XXI Editores, 1997 (22a. reimp.).

BRISCOE, John, "Roma y la lucha de clases en los Estados griegos, 200-146 a. d. C.”, en M. I. Finley, Estudios de Historia Antigua, trad. de Ramón López, Madrid, Akal (Akal Universitaria, 8), 1981, pp. 65-85.

CAMERon, Averil, El mundo mediterráneo en la Antigüedad tardía (395600 ), trad. de Teófilo de Lozoya, Barcelona, Crítica (Crítica Arqueología), 1998.

ChURRUCA, Juan de, Introducción histórica al Derecho Romano, Bilbao, Universidad de Deusto, 1994 (7a. ed.).

Cornell, T. J., Los orígenes de Roma, 1000-264 a. C. Italia y Roma de la Edad del Bronce a las guerras púnicas, trad. de Teófilo de Lozoya, Barcelona, Crítica (Crítica Arqueología), 1999.

FERRIL, Arther, La caída del Imperio Romano. Las causas militares, trad. de Pilar González Bermejo, Madrid, EDAF (Biblioteca EDAF, 232), 1998.

Hobsbawm, Eric, "El sentido del pasado", en Sobre la historia, trad. de Jordi Beltrán y Josefina Ruíz, Barcelona, Crítica, 1998, pp. 23-37.

Homo, Leon, Evolución social y política de Roma, trad. de C. López Nieves, México, Editorial Argos, 1944.

Hopkins, Keith, "La Romanización. Asimilación, cambio y resistencia", en Jaime Alvar y José María Blázquez (eds.), La Romanización en Occidente, Madrid, Actas Editorial, 1996, pp. 15-43.

—, "Movilidad de la élite en el Imperio Romano", en M. I. Finley, Estudios de Historia Antigua, trad. de Ramón López, Madrid, Akal (Akal Universitaria, 8), 1981, pp. 119-136. 

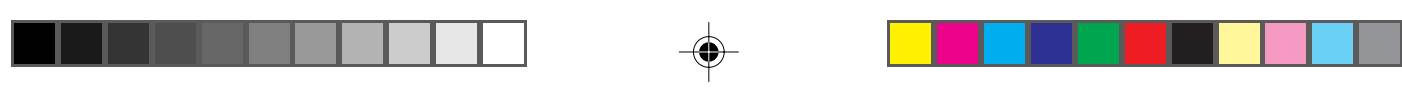

Huskinson, Janet, "Elite culture and the identity of empire", en Janet Huskinson (ed.), Experiencing Rome. Culture, Identity and Power in the Roman Empire, Londres, Routledge-The Open University, 2000, pp. 95-123.

KunKel, Wolfgang, Historia del Derecho Romano, trad. de Juan Miquel, Barcelona, Airel (Ariel Derecho), 1989 (1a. reimp.).

Maravall, José Antonio, Antiguos y modernos. Visión de la historia e idea del progreso hasta el Renacimiento, Madrid, Alianza Editorial (Alianza Universidad, 458), 1985 (2a. reimp.).

Mazzolani, Lidia Storoni, The idea of the city in Roman thought. From walled city to spiritual commonwealth, trad. de S. O. Donell, Bloomington y Londres, Indiana University Press, 1970.

MiLes, Richard, "Communicating culture, identity and power", en Huskinson, op. cit., pp. 29-62.

Sherwin-White, A. N., The Roman Citizenship, Oxford, Oxford University Press (2a. ed.), 1973.

Ste. Croix, G. E. M. de, La lucha de clases en el mundo griego antiguo, trad. de Teófilo de Lozoya, Barcelona, Crítica (Crítica Arqueología), 1988.

Syme, Ronald, La revolución romana, trad. de Antonio Blanco Freijeiro, Madrid, Taurus (Taurus Humanidades), 1989.

Veyne, Paul, "El imperio romano", en Georges Ariés y Georges Duby (dirs.), Historia de la vida privada, trad. de Francisco Pérez y Javier Arce, Madrid, Taurus, 1989 (6a. reimp.), 5 v. V. 1, pp. 9-227. 